Journal of Environmental Law 23:1 (C) The Author 2011. Published by Oxford University Press. All rights reserved. For Permissions, please email: journals.permissions@oup.com doi:10.1093/jel/eqq025 Advance Access published on 7 January 2011

\title{
Is Precautionary Regulation a Civil Law Instrument? Lessons from the History of the Alkali Act
}

\author{
Noga Morag-Levine*
}

\begin{abstract}
Explanations for cross-national divergence in attitudes towards precautionary regulation have largely neglected the potential influence of legal traditions, notably the tension between precautionary tools and the common law's reactive approach. This is partially due to the apparent clash between this thesis and the early emergence in Britain of precautionary regulation under the 1863 Alkali Act. Historical accounts of this development have focused entirely on domestic factors, entrenching in the process an understanding of the Alkali Act - and Britain more generally - as the origin of centralised precautionary environmental regulation. In contrast, this article argues that the Act was directly inspired by French and other continental regulatory models, and that the regime it spawned constituted a continental-common law hybrid. If the Alkali Act regime was partially transplanted from the Continent, it becomes easier to reconcile the civil law character of precautionary regulation with the evident presence of that instrument in Victorian Britain.
\end{abstract}

Keywords: Alkali Act, precautionary, legal transplants, technology standards, legal traditions

*Associate Professor, Michigan State University College of Law (nmorag@law.msu.edu). This article greatly benefited from comments provided by Jonathan Levine, David Schorr, David Sugarman, Frank Uekoetter and Chris Hilson. For assistance with translations I thank Julien Landry and James Leiby. Finally, I owe a special debt to the library staff at MSU College of Law, in particular, Kathy Prince, Brent Domann, and Tony Jesko. 


\section{Introduction}

Recent disagreements between the United States and the EU over precautionary regulation closely parallel those that have for centuries split common law from continental civil law-based approaches to health and safety regulation. In legitimating regulatory interventions in the absence of scientific proof of harm, the precautionary principle departs from the common law's insistence, most importantly within the framework of public nuisance litigation, that the state carry the burden of proof on causation as a precondition for regulatory intervention. Notwithstanding that, differences in legal tradition have generally been left out of efforts to explain recurrent trans-Atlantic tensions over the status of the precautionary principle. ${ }^{1}$

In similar fashion, common law ideology took a backseat to other explanations when differences between the continental European and British approach to regulation became apparent soon after Britain joined the European Community. The latter disagreement, revolved in large part over British resistance to the German-led push for the implementation of uniform, technologybased, pollution control standards. ${ }^{2}$

In Germany reliance on technology standards of this type was a core element of the Vorsorgeprinzip, the emergent framework principle of German environmental policy during the 1970s. In the context of German air pollution regulation, where the principle was first introduced, Vorsorge counseled a policy of incremental reduction of emissions, by all sources, even in the

1 M Faure and N Vig, 'Conclusion: The Necessary Dialogue' in M Faure and N Vig (eds), Green Giants? Environmental Policies of the United States and the European Union (The MIT Press, Cambridge, MA 2004) 347; C Sunstein, 'Precautions Against What? The Availability Heuristic and Cross-Cultural Risk Perception' (2005) 57 Ala L Rev 75; J Wiener and M Rogers, 'Comparing Precaution in the United States and Europe' (2002) 5 J Risk Res 317; D Vogel, National Styles of Regulation: Environmental Policy in Great Britain and the United States (Cornell University Press, Ithaca, New York 1986). Cf N Morag-Levine, Chasing the Wind: Regulating Air Pollution in the Common Law State (Princeton University Press, New Jersey 2003).

2 Speaking directly to this controversy, a report published in Britain in 1975 by the Department of the Environment noted the recent emergence of significant difference between the 'United Kingdom and some of its partners' over the deployment of 'uniform emission standards.' The report attributed this tension to the incompatibility of such standards with the characteristic British approach under which

... [i]t is important to concentrate on those areas where there is a need for control for health reasons; and for the rest where effective control can be achieved at a cost proportionate to the damage... Where the nature of the receiving medium and the local climatic, social and industrial conditions are such that the natural environment can be relied on to disperse and degrade the pollutant efficiently, then it makes sense to rely on the environment to do the job of purification and disposal rather than take unnecessary remedial action.

Department of the Environment, Environment Standards: A Description of United Kingdom Practice: The Report of an Interdepartmental Working Party (Pollution paper no 11, HMSO, London 1977) 20. 
absence of conclusive evidence on cause-and-effect relationships between exposure to particular pollutants and identifiable environmental harms. ${ }^{3}$ Rather than conditioning regulatory interventions on scientific proof of the risks of pollution, Vorsorge, generally translated as 'precaution', promoted the implementation of existing means of pollution reduction and the development of cleaner industrial processes. ${ }^{4}$ When Germany sought during the 1980s to make this principle a cornerstone of European environmental policy it met significant British scepticism.

Accounts of this UK-German divergence placed little emphasis on differences in legal tradition and the tension between the proactive philosophy underpinning the Vorsorgeprinzip and the common law's reactive regulatory principles. Instead, the leading explanation tied British resistance to Germany's technology-based approach to Britain's geographic isolation and distinct weather patterns. In this vein, a leading environmental law treatise offered the following: "[t]he main argument for the British position probably stems from self-interest. With its rainy climate and fast-running streams, ample coastline and relative remoteness, Britain can claim a comparative advantage when it comes to pollution. Put very crudely, the same discharge is supposed to cause less pollution in Britain than in other countries, because of its lesser effect on the environment,. The parsimony of the argument from climate and geography and its consistency with interest-based theories of comparative politics lends this line of explanation a surface appeal. But its persuasiveness is undercut by the fact that there is little history to support the notion that Britain enjoyed, by virtue of its geography, superior protection against injury from pollution. Britain of the 19th and early 20th centuries was notorious for its smog, noxious vapours from copper smelting, alkali and other manufacturing and sewage-contaminated rivers. Moreover, anecdotal comparisons drawn over a long period have tended to describe environmental conditions in Britain as inferior to those of the Continent, further detracting from the capacity of climate and geography to explain cross-channel differences in regulatory approach. ${ }^{6}$ If the argument from geography nonetheless

3 A Weale and others, Environmental Governance in Europe: An Ever Closer Ecological Union? (OUP, Oxford 2000) 67.

4 S Boehmer-Christiansen, 'The Precautionary Principle in Germany-Enabling Government' in T O'Riordan and J Cameron (eds), Interpreting the Precautionary Principle (Earthscan, London 1994) 31, 36-37.

5 S Ball and S Bell, Environmental Law: The Law and Policy Relating to the Protection of the Environment (Blackstone Press, London 1995) 101. For similar weather and geography-based explanations for the emergence of a distinct British approach to pollution see Vogel (n 1) 103; $\mathrm{R}$ Wurzel, Environmental Policy-Making in Britain, Germany and the European Union (Manchester University Press, New York 2002) 7; L Cass, 'The Indispensable Awkward Partner: The United Kingdom in European Climate Policy' in P Harris (ed), Europe and Global Climate Change (Edward Elgar Publishing Ltd, Cheltenham 2007) 66.

6 Already by the 1640 s the superiority of atmospheric conditions in Paris relative to London is said to have inspired the interest of Sir Kenelm Digby and John Evelyn (both Royalists who escaped to Paris after Parliament assumed power) in air quality improvement. Noting that 
superseded common-law-based explanations, it is partially due to the longstanding significance of technology standards in British environmental regulation dating back to the Alkali Act of $1863 .^{7}$ Parliament initially enacted the Alkali Act in response to widespread injury from hydrochloric acid from alkali manufacturers, injury that existing common law institutions seemed to tolerate notwithstanding the availability of feasible means of mitigation. Through various iterations over the next century, the Act expanded its jurisdiction to numerous industrial processes and air pollutants. The principle underpinning the Act's enforcement regime throughout the 19th and 20th centuries (as well as additional British environmental legislation that followed in its step) was a duty on the part of industrial sources 'to use the best practicable means for preventing the emission into the atmosphere from the premises of noxious or offensive substances.' 8 As Nigel Haigh, the founder and longtime director of the Institute of European Environmental Policy has written: to the extent that the precautionary principle, in keeping with the early German perspective, is equated with the setting of achievable technology standards, the Alkali Act could be said to have introduced the precautionary principle into Britain. ${ }^{9}$ Regarding the question of whether the Alkali Act is better seen as an example of the 'precautionary principle', which entails uncertainty, or the 'principle of prevention' that assumes a proactive response to a known harm, Haigh pointed to the fact that 'uncertainty about when uncertainty disappears' makes the distinction between the principles difficult to implement. The ambiguous boundary between precaution and prevention is especially well-illustrated through the mix of concerns to which the Alkali Act provided a response. Widespread injury to property from the noxious vapours in question offered clear-cut justification for preventive intervention, but worry over the potential, though unproven, health effects was an important impetus as well. ${ }^{10}$ Preventive regulation was the more common term at the time, though references to precaution can likewise be found. It appears that within this 19 th century context the concepts were largely interchangeable. ${ }^{11}$

'[t]he air of London was worse than that of Paris or Liège' Digby advised 'people with weak lungs and plenty of money' to live on the Continent. P Brimblecombe, The Big Smoke: A History of Air Pollution in London Since Medieval Times 46 (Methuen, London 1987). Similar sentiments were expressed in an 1853 article in a medical newsletter which declared '[w]e do not despair of seeing London freed [from smoke], its inhabitants breathing as pure and clear an air as those of Paris, Berlin, or Vienna.' 'The Smoke Nuisance' The Medical Times and Gazette, A Journal of Medical Science (Jul 2 - Dec 31 1853), 196, 197.

7 Alkali Act 1863 (26 \& 27 Vict c 124).

8 M Hill, 'The Role of the British Alkali and Clean Air Inspectorates in Air Pollution Control' (1982) 11 Poly Stud J 165.

9 N Haigh, 'The Introduction of the Precautionary Principle into the UK' in T O'Riordan and J Cameron (eds), Interpreting the Precautionary Principle (Earthscan, London 1994) 241.

10 R MacLeod, 'The Alkali Acts Administration, 1863-84: The Emergence of the Civil Scientists' (1965) 9 Victorian Stud 85, 87, 102.

11 For examples of the use of the term 'precautionary' as a synonym for 'preventive' see text accompanying nn 40 and 56. 
Importantly, the various extant historical accounts have treated the introduction of the Best Practicable Means (BPM) principle under the Alkali Act as an indigenous British development. ${ }^{12}$ This reading of the history of the Alkali Act regime has eroded the explanatory power of legal traditions where the origins of cross-national differences in environmental regulatory instruments are concerned. This is because, if, as the prevailing account suggests, common law Britain was an early and leading adopter of precautionary technology standards, the evidence appears to cut against any underlying connection between technology standards and the regulatory sensibilities associated with the civil law tradition. Conversely, if, as this article will argue, the Alkali Act regime was in fact inspired and modelled after preexisting continental examples, the early presence of technology standards in Britain is not inconsistent with the understanding of precautionary regulation as an essentially continental approach.

The place of continental influences in the Alkali Act's passage and implementation was not central to the concerns of the historians who were first to study the Alkali Act's history and to whose efforts we are indebted for our understanding of the Act's watershed significance in the annals of environmental history. ${ }^{13}$ In explaining the emergence of the Alkali Act regime, these accounts have tended to highlight domestic political forces such as the power of injured landowners whod grown frustrated with nuisance law's failure to mitigate the pollution. The impression left as a consequence was that the Alkali Act was born in England in isolation, and perhaps even in advance, of any parallel initiatives on the Continent. ${ }^{14}$ In actuality, however, references to continental pollution control practices are replete in the historical record surrounding the Act's initial passage and subsequent implementation, including various parliamentary reports and debates. This evidence offers strong support for the conclusion that the Alkali Act's precautionary, technology-based, approach was consciously patterned after preexisting continental practices, even

12 MacLeod (n 10); E Ashby and M Anderson, The Politics of Clean Air (Clarendon Press, Oxford 1981); A Dingle, 'The Monster Nuisance of All: Landowners, Alkali Manufacturers, and Air Pollution, 1824-64'(1982) 35 Econ Hist Rev 529; B Pontin, 'Integrated Pollution Control in Victorian Britain: Rethinking Progress within the History of Environmental Law' (2007) 19 JEL 173.

13 Ibid.

14 The author of a recent treatise on EU Environmental law commented on the tendency of some British authors to describe the Alkali Inspectorate as 'the world's first national pollution control agency' while disregarding the 'older French and Prussian regime.' E Bohne, The Quest for Environmental Regulatory Integration in the European Union (Kluwer Law International, Alphen aan den Rijn 2006) 102 fn 2. For some such references to the Alkali Inspectorate as the 'world's first national pollution control agency' see S Bell and D McGillivray, Environmental Law (6 ${ }^{\text {th }}$ edn OUP, Oxford 2006) 22; Weale and others (n 3) 151; National Center for Environmental Innovation, An In-depth Look at the United Kingdom Integrated Permitting System (US Environmental Protection Agency, National Center for Environmental Innovation, Washington DC 2008) 7. 
as these were adapted to British political sensibilities in the course of this transplantation process.

The existence of systematic differences between British and continental approaches to pollution was commented upon by mid-19th century observers across both sides of the Channel. To these observers, in contrast with the 20th century writings discussed above, the respective influence of common law and civil law principles stood as the evident explanation for the divergence between British and continental pollution control practices. Most importantly, these differences were said to revolve around the choice between proactive and reactive modes of intervention. The continental paradigm imposed proactive controls on the location of polluting industries and the processes they employed through administrative licensing and enforcement mechanisms. In Britain, in contrast, industrial sources faced no a priori requirements as to proper location or necessary controls. Within this reactive regime, regulatory interventions were contingent on the presence and success of private and public nuisance lawsuits. ${ }^{15}$ The evident deficiencies of this common law regime encouraged, during the 1850s and early 1860s, a variety of initiatives geared at the introduction of continental pollution control practices into Britain, as the article will discuss.

The constitutionality of continental regulatory practices was a matter of sharp controversy in Britain during the mid-19th century. Central to this controversy was the movement for sanitary reforms, best associated, perhaps, with the name of Edwin Chadwick, and the Public Health Act of $1848 .^{16}$ These reforms, as discussed below, encountered strong resistance in the shape of an anti-centralisation movement which denounced the era's sanitary reforms as illegitimate deviations from traditional common law institutions and principles. If the Alkali Act regime was largely spared this fight it was likely because its architects and implementers, determined not to repeat Chadwick's mistakes, were careful to distance their project from direct association with the Continent and adapted it in a fashion that ultimately yielded the earlier discussed BPM principle. In muting the contrast between Britain and the Continent this transplantation process also diverted attention away from the common law's influence where the cause of remaining differences between British and continental regulatory principles was concerned.

The remainder of this article proceeds as follows: Part 2 traces the historical origins of the British and continental approaches, the contribution of differences in legal tradition to their divergences, and, in particular, the role of common law ideology within the political opposition to continental-inspired regulatory reforms in the decade and a half leading to the Alkali Act of 1863. 
Part 3 follows the evolution of the Alkali Act regime from the 1862 Parliamentary Select Committee hearings that led to the Act's passage up to the 1884 death of Angus Smith, the first Chief Inspector of the Alkali Inspectorate. Throughout this period, the discussion focuses on the role of continental models in the debates surrounding the Act's initial passage, amendments and implementation and the convergence of continental and common law influences under BPM. In conclusion, the article comments briefly on the continuing salience of this historical tension in contemporary international divisions over precautionary regulatory instruments.

\section{Legal Traditions and the Origins of the Continental and British Approaches to Environmental Regulation}

The legislative process that would result in the passage of the Alkali Act of 1863 was begun by Lord Derby a year earlier in a speech in which he called on the House of Lords to appoint a select committee on the problem of noxious vapours. ${ }^{17}$ In his hands, offering what is perhaps the most direct piece of evidence linking the origins of the Alkali Act with French influences, he held a report entitled The Laws and Ordonnances in Force in France for the Regulation of Noxious Trades and Occupations. Careful to insist that he "was not going to ask their Lordships to imitate the principles or practice of the French law, the provisions of which were very stringent in such cases' Lord Derby nonetheless went on to quote a lengthy paragraph detailing the authorisation of potentially noxious industrial processes under French law. ${ }^{18}$ The report from which Lord Derby quoted had been presented to both houses of Parliament in 1855 and was commissioned by then Home Secretary Viscount Palmerston. ${ }^{19}$ Implicit to that report's conclusion was a recommendation that England adopt regulatory institutions similar to the French 'system of keeping an active supervision by means of a department of the Police (Hygiène Publique et Salubrité) over the noxious trades and occupations likely to interfere with the public health. ${ }^{20}$

A treatise on the regulation of noxious trades, published in Brussels in 1857 and written by the Chief of the Belgian Interior Ministry, Jules Vilain, likewise highlighted the contrast between the principles that governed the regulation of the offensive impacts of such trades in England, and those that applied on

18 Ibid.

19 Dr WA Lewis, Report of the Laws and Ordinances in Force in France, for the Regulation of Noxious Trades and Occupations (HMSO, London 1855).

20 Ibid 504. 
the Continent. Vilain summed up the pertinent difference in the following terms:

On the continent the system adopted has been preventive with the guardianship of the administration. The administrative authority is fortified with preventive power, and the right of refusing permission to the existence of establishments dangerous, unwholesome, or inconvenient. The English on the contrary, have adopted the repressive system. To let alone that which is well, to prevent by penal laws that which is bad by the action of the courts of law, is amongst the English the national rules, and that of the public authorities. To respect liberty in all working establishments, to repress amongst them all offensive acts such is the principle of the common law and the instinctive tendency very generally of the country. $^{21}$

As this quotation suggests, at the middle of the 19th century, British and continental regulatory practices were understood to diverge in a fundamental respect. On the Continent, industrial facilities could operate only with the permission and license of the pertinent authorities. Licensing served as a tool through which the location and manner of operation of potentially offensive trades could be controlled in advance. In Britain, industrial operators were not required to obtain a licence in advance, and could choose their location and mode of operation as they saw fit. To the extent that their activities inflicted harm on their surroundings they faced the risk of lawsuits that could in principle result in the payment of damages or injunctions requiring that they move elsewhere or mitigate their pollution. But, in contrast with the "preventive power' present on the Continent, in Britain, regulatory interventions were by necessity post hoc and dependent on proof of injury before a court. This reactive feature was what set British regulatory institutions apart.

To mid-19th century observers such as Vilain, the role of the common law tradition in forging these differences was evident, in contrast to the marginality accorded to legal traditions within the context of contemporary comparisons. If the common law's salience has in time receded from view, this is likely due to the later success of regulatory reform efforts aimed at adopting a more preventive, or precautionary, approach along the continental model. Before turning in Part 3 to the manner in which the Alkali Act came to blend continental with common law regulatory principles, the following sections focus on the common law's role in the creation and maintenance of the initial distinction between the British and continental approaches.

21 J Vilain, Traitè Théorique et Pratique de la Police des Éstablissements Dangereux Insalubres ou Incommodes (A Theoretical and Practical Treatise on the Regulation of Dangerous, Unhealthy, or Noisome Trades.) (Émile Flatau, Brussels 1857) 496. 


\subsection{Legal Traditions and the Division between Preventive and Reactive Regulation}

The law governing the regulation of noxious trades across much of continental Europe during the mid-19th century was based on a Napoleonic decree originally issued in 1810, and subsequently confirmed and modified in 1815. The law was motivated by two sets of concerns associated with noxious trades: worker safety and neighbourhood impacts. ${ }^{22}$ The primary regulatory instrument it relied on for this purpose was a requirement that the construction of listed 'dangerous, unhealthy or noisome trades be authorised, following investigation into the proposed project's location, environmental impact and industrial processes. ${ }^{23}$ The licensing requirement created a mechanism for directing polluting industrial activity into separate zones, and away from residences where possible. More important where the history of precautionary technology standards is concerned, was the occasional imposition as part of these pre-authorisation procedures of specific technology-based requirements for pollution mitigation. This was the case in France where steam engines fitted with smoke-consuming technology were put in a less stringent category than engines that did not consume their smoke. In practice, this meant that operators of steam engines in cities faced the choice of either upgrading their pollution control techniques or moving out of town. ${ }^{24}$

The licensing procedures encoded under the 1810 decree were rooted in the longstanding mercantilist practices of absolutist French monarchs, most directly the granting of monopolies and industrial privileges. ${ }^{25}$ The legal theory at

22 R Wolf, Der Stand der Technik: Geschichte, Strukturelemente und Funktion der Verrechtlichung technischer Risiken am Beispiel des Immissionsschutzes (The State of Technology: History, Structure and Function of the Legal Regulation of Technical Risks-the Example of Immission Control) (Opladen, Westdeutscher Verlag 1986) 47.

23 The initial 1810 decree included 66 industries among those subject to a pre-authorisation requirement; by 1846 the number increased to 307. I Mieck, 'Luftverunreinigung und Immissionsschutz in Frankreich und Preußen zur Zeit dur fruhen Industrialisierung' (Air Pollution and Immission Control in France and Prussia in the Early Industrial Age) (1981) 48 Technikgeschichte 239, 242. These were divided into three categories, in accordance with their expected environmental impact. The most stringent requirements applied to facilities categorised under class 1, which could only be established away from residences. Manufacturers and workshops falling under the second class could under some circumstances and with proper surveillance be licensed in proximity to residences, whereas those falling under the third category were generally deemed compatible with residential land uses, though they too were subject to administrative surveillance.

24 Ibid 248.

25 In a study of the 18th century French roots of contemporary environmental regulation, Reynard describes the mechanisms through which environmental concerns entered the process surrounding requests for industrial privileges. These began with the role of expert evaluation of the proposed operation and its impact, and continued with a public inquiry, which served as a venue for voicing local concerns. Because industrial activity in France during that time was for all intents and purposes dependent on the granting of a royal privilege, the latter 'amounted to an authorization procedure that often entailed a public inquiry into the implications of the venture.' PC Reynard, 'Public Order and Privilege: Eighteenth-Century French Roots of Environmental Regulation' (2002) 43 Technol Cult 1, 26. 
the basis of French absolutism drew from Roman law principles of public law, and attendant conceptions of the ruler's prerogative authority to supersede private rights where the common good demanded it. ${ }^{26}$ Based on this authority, absolutist rulers across Europe argued for the right to intervene in economic relations through unrestrained ordaining powers free of any other institutional constraint. ${ }^{27}$

In pursuing their own mercantilist policies, English monarchs similarly invoked prerogative legislative authority. But their efforts were severely weakened by the existence in England of a formidable alliance between Parliament and common-law-trained legal professionals who challenged the constitutionality of absolutist, civil-law-based regulatory instruments. Particularly relevant to the present discussion was the influential belief that royal monopolies and privileges were contrary to common law principles of freedom of trade. ${ }^{28}$ The victory of Parliament and the common lawyers after the Revolution of 1688 all but ended centralised regulation of industrial activity for at least a century to come. At the very same moment that French absolutism reached its centralising epoch under Louis the IIV, in England the 'King and Parliament adopted a policy of indifference as to what the various local governing authorities did or abstained from doing. ${ }^{29}$ Coupled with this localism, and further distinguishing it from the Continent, was the relegation of enforcement procedures to reactive judicial processes run by lay justices rather than a professional bureaucracy of the French type. ${ }^{30}$

Thus it happened that instead of proactive limits on the location and processes of industrial activity under a licensing regime, the regulation of noxious trades in England of the 18th and early 19th century built on a core common law principle allowing for regulatory intervention in the face of evident harm, or nuisance. Coke justified this principle in reference to the Latin maxim sic utere tuo ut alienum non laedas' (use your own without injuring another) in his report of a landmark case involving the stench of a pigsty. ${ }^{31}$ Blackstone cited

26 G Post, Studies in Medieval Legal Thought: Public Law and the State, 1100-1322 (Princeton University Press, New Jersey 1964) 343.

27 As Louis XV declared to the parliament of Paris: 'It is from me alone that my courts derive their existence and authority ... and it is to me alone that supreme and undivided legislative power belongs.' B Pierce (tr), R Mousnier, The Institutions of France under the Absolute Monarchy, 1598-1789, (University of Chicago Press, Chicago 1979) 669.

28 Particularly important to this development were a number of judicial decisions deeming monopolistic restrictions on the freedom of the subject void under common law. M Shapiro (tr), E Heckscher, Mercantilism (Allen \& Unwin, London 1955) 282. Building on this doctrine, Parliament prohibited the granting of most industrial monopolies under the 1623 Statute of Monopolies, and again in 1640. J Nef, Industry and Government in France and England, 1540-1640 (Great Seal Books, Ithaca 1957) 362.

29 S Webb and B Webb, English Local Government: Statutory Authorities for Special Purposes (Longsman, Green and Co, London 1922) 351.

30 HW Arthurs, 'Without the Law': Administrative Justice and Legal Pluralism in Nineteenth-Century England (University of Toronto Press, Toronto 1985) 90-91.

31 Aldred's Case (1611) 77 ER 816. 
the maxim to explain why it is incumbent [on a neighboring owner] to find some other place', if the neighbour's use of his land 'causes injury to the land of another. ${ }^{32}$ In addition to private actions, violations of the sic utere principle could result in criminal indictments where the pertinent injury qualified as a common, or public, nuisance. As Blackstone explained: "[a]ll those kinds of nuisances (such as offensive trades and manufactures) which when injurious to a private man are actionable, are, when detrimental to the public, punishable by public prosecution, and subject to fine according to the quantity of the misdemeanor: and particularly the keeping of hogs in a market town. ${ }^{33}$

Public nuisances were indictable before lay justices of the peace in local courts. ${ }^{34}$ Where found to constitute such a nuisance, noxious trades could be subject to summary abatement orders. A 1757 decision concerning the manufacturer of sulphuric acid and other chemicals in the Parish of Tickenham attests to the scope and potential reach of this authority. According to the indictment in the case "the defendants erected 20 buildings for making noisome, stinking, and offensive liquors; ... [impregnating the air] with the noisome and offensive stinks and smells; to the common nuisance of all the King's liege subjects. ... 35 Having been found guilty of the said nuisance, the defendants were ordered to demolish the facility with the "materials, utensils and instruments, all sold or parted with. ${ }^{36}$ Abatement orders of this type became, however, increasingly rare as industrialisation progressed. The reported cases for the century following 1770 suggest that few air pollution nuisance cases reached the courts to begin with, and that when they did, judges often sided with industry. ${ }^{37}$ This was true not only with respect to lawsuits brought by individuals under private nuisance doctrines, but also of criminal indictments in public nuisance. ${ }^{38}$

The result was widespread failure on the part of industrial sources to undertake pollution control measures, even as these became available. The connection between the reactive principles of British regulation and inferior pollution control practices in Britain, relative to the Continent was commented upon by a senior French official whom Vilain quoted in the treatise mentioned above. $^{39}$ In the absence of any licensing requirements of the type existing on the Continent, that official explained, the door was open in Britain for:

... a manufacturer with great capital [to establish] himself in a poor quarter where there is no fear of opposition. Abusing his position he

32 W Blackstone, Commentaries on the Laws of England (vol 2, $2^{\text {nd }}$ edn Callahan and Company, Chicago 1872) 217.

33 Ibid 168

34 Webb and Webb (n 29) 351-52, 463.

35 Rex vWhite \& Ward (1757) 97 ER 338.

36 Ibid.

37 JP McLaren, 'Nuisance Law and the Industrial Revolution - Some Lessons from Social History' (1983) 3 OJLS 155, 159-60.

38 J F Brenner, 'Nuisance Law and the Industrial Revolution' (1974) 3 J Legal Stud 403, 421.

39 Vilain (n 21). 
takes none of these precautions which would have been imposed on him in other countries, either to consume his smoke, disinfect his gas, or diminish the noise of the machinery. The result is that all the population is exposed without protection to deleterious exhalations and inconveniences of every kind. ${ }^{40}$

The British regime's core deficiency, in the eyes of this observer, was not that it allowed for massive amounts of pollution. Notwithstanding the existence of preventive regulation, industrial pollution remained a serious concern on the Continent as well. Where the British approach failed, instead, was in the implementation of incremental mitigation measures capable of reducing, albeit not eliminating, environmental injuries.

This criticism was shared by those in Britain who sought to introduce into British regulation a more preventive or precautionary orientation during the mid-19th century. Thus the earlier mentioned 1855 report to Parliament included multiple examples of the types of pollution mitigation various French trades were required to undertake as a condition of their permits. As that report related in France '[t]he Boards of Health only authorize manufactories of Prussian blue [a synthetic pigment] on condition that all the flues and chimneys of the boilers communicate with the chimney, 15 feet in height, and that the water of manufactory shall not remain either in the culverts, trenches, or public ways. ${ }^{41}$ Elsewhere the same report referenced a requirement that brick manufacturers surround their furnaces with mattresses stuffed with straw to protect surrounding properties from smoke, ${ }^{42}$ and that elevated chimneys be constructed where mercury was used in the gilding of metals. ${ }^{43}$ Commenting on the French industries he had had the occasion to observe, the report's author, Dr Waller Lewis, noted that '[m]any of these are models of what such manufactories should be'. And he went on to contrast the '[n]ew and improved processes [that] have been introduced in these and other factories' with the 'the old, objectionable, and unhealthy methods still all but universally employed' in Great Britain. ${ }^{44}$ By implication, Lewis attributed the inferior industrial processes in England to the absence of licensing provisions of the type the 1810 Decree imposed on French businesses. In this, England was set apart not only from France, but also from Belgium, the Netherlands, Prussia and other continental countries where French law spread at the start of the 19th century through Napoleon's conquest and influence, and where subsequent domestic legislation bore the imprint of the 
original Napoleonic Decree. ${ }^{45}$ Attempts to bring British pollution and related sanitary regulation in closer alliance with the preventive continental model recurred in Britain for at least two centuries prior to the passage of the Alkali Act of 1863. Throughout this history, those who sought to learn from continental administrative examples and considered the civil law a legitimate inspiration collided with those for whom the common law's reactive regulation was a core constitutional principle, as discussed below.

\subsection{Continental-Inspired Proposals for British Sanitary Reform}

Efforts to bring polluting trades in Britain under preventive regulation patterned after the continental model date at least as far back as the 17th century writings of John Evelyn (1620-1706). A royalist sympathiser, Evelyn left England for the Continent in 1643 where he stayed until 1652, most of this time in Paris. ${ }^{46}$ Soon after the Restoration of the Monarchy in 1660, Evelyn presented Charles II with a pamphlet titled Fumifugium: or the Inconvenience of the Aer and Smoake of London Dissipated (1661). ${ }^{47}$ In it Evelyn described a London engulfed in a 'Hellish and dismal Cloud of SEA COAL', which rendered its inhabitants 'obnoxious to a thousand inconveniences, corrupting the Lungs, and disordering the entire habits of their Bodies. ${ }^{48}$ Evelyn repeatedly contrasted London's poor air quality with that which he enjoyed in France, and advocated a number of proposals drawing upon his observation of planning practices on the continent. Most importantly, Evelyn recommended that trades causing manifest nuisances be placed 'at farther distances; especially, such as in their works and Fournaces use great quantities of Sea-Coale... which so universally and so fatally infect the Aer, and would in no City of Europe be permitted, where Men had either respect to health or Ornament. ${ }^{49}$ He then specifically identified brewers, dyers, soap and salt boilers and lime burners as examples of the types of trades his proposal would target for removal. ${ }^{50}$

More than a century later, the anonymous editor of a reprinted 1772 edition of Fumifugium prefaced the work with an explanation of its continued and even enhanced, relevance during his time. ${ }^{51}$ The industrial revolution had

45 Prussia, for instance, enacted in 1845 a General Trade Ordinance that required industries with potential to pollute the air, such as tanneries, metal casters and gas works, to abide by conditions to be specified in their permits. Wolf (n 22) 71; Vilain (n 21) 529.

46 - 'Encyclopedia Britannica Online Entry for John Evelyn' Britannica <http://www .britannica.com/EBchecked/topic/197048/John-Evelyn > accessed 25 August 2010.

47 J Evelyn, Fumifugium: or, The Inconvenience of the Aer and Smoak of London Dissipated (B White London, 1772).

48 Ibid 5.

49 Ibid 15.

50 Ibid.

51 Ibid iii-vii. 
added new trades such as 'Glass-houses, Foundries and Sugar bakers' to the list of noisome facilities that Evelyn recommended be removed from the city. But the underlying problem remained the absurd policy of allowing [noxious trades such as] brewers, Dyers, Soap-boilers and Lime-burners to intermix their noisome works amongst the dwelling-houses in the City and Suburbs, ${ }^{52}$ Acknowledging that a "proposal of turning all the noxious Trades at once out of town may be thought impracticable, as being inconsistent with the general Liberty of the Subject, ${ }^{53}$ the preface writer suggested a number of alternative proposals compatible, in his opinion, with the enforcement powers of local magistrates. These included both 'proper indulgences' for the operators of noxious trades to build their facilities at sufficient distance from town so as to give incentives for existing facilities to relocate, as well as a bar against the construction of new polluting trades inside towns. A second line of recommendations focused on the implementation of technological mitigation measures ranging from higher and better constructed chimneys to concerted research aimed at devising a "method for charring sea-coal, so as to divest it of its smoke. ${ }^{54}$

In advocating this ambitious smoke control agenda the author of the above proposals accorded with the reformist spirit that swept into Britain from the continent during the closing decades of the 18th century. On the continent the 18th century brought a marked expansion in the state's role in the mitigation of economic and social deprivations and an attendant growth in the state's regulatory authority and capacity. ${ }^{55}$ In pursuing these reform agendas, continental rulers enacted detailed codes and entrusted their implementation to an extensive bureaucratic apparatus. The term 'police' (a translation of the German Polizei) came to serve in this context as a shorthand reference for the totality of regulatory philosophy and institutions comprising this continental approach. In Britain there were strong voices, most prominently that of Jeremy Bentham, who promoted comprehensive reforms of British regulatory institutions along the continental model. Reforms of this type entailed a shift away from the traditionally reactive common law approach towards proactive intervention. Terming reactive regulation 'justice' and preventive law 'police', Bentham explained the difference in the following: '[j] ustice regards in particular offences already committed; her power does not display itself till after the discovery of some act hostile to the security of the citizens. Police applies itself to the prevention both of offences and calamities; its expedients are, not punishments, but precautions; it foresees evils, and provides against wants. $^{56}$

52 Ibid iii.

53 Ibid iv.

54 Ibid v.

55 A Burns and J Innes (eds), 'Introduction' in Rethinking the Age of Reform: Britain 1780-1850 (CUP, Cambridge 2003) 11-12.

56 Jeremy Bentham, 'Chapter II. Sub-division of Offences' in C Ogden (ed), The Theory of Legislation (K Paul, Trench, Trubner \& Co Ltd, London 1931) 242. 
To Bentham the superiority of the continental model over a common law system that, similarly to the methods used in the training of dogs, waited until an offence took place to issue a rule, was clear and obvious. ${ }^{57}$ But his reform proposals failed to make headway in Britain against trenchant opposition from judges, lawyers and other defenders of the common law.

By the start of the 19th century the reformist impulses in British politics subsided considerably as those in Britain whod long warned against the despotic tendencies of continental institutions pointed in vindication to the tyranny unleashed in the wake of the French revolution. ${ }^{58}$ The Revolution and the Napoleonic wars isolated Britain from the continent, spawned fear of the dangers of tampering with existing political institutions, and set back the agendas of British reformers. ${ }^{59}$ By the 1830s the moment was once again ripe for political change, epitomised by the passage of the Reform Act of $1832 .^{60}$ The sanitary crisis in the crowded and rapidly industrialising British cities was among the problems Parliament was called upon to address.

Demands for government intervention in matters of sanitary policy drew on a growing body of statistical evidence indicative of the interconnections between poverty, filth and disease. ${ }^{61}$ Viewed through this lens, sanitary reform was justified as a public health measure and as such a legitimate sphere for regulation even under principles of political economy and laissez-faire. Growing attention to sanitary reform in Britain of the late 1830s and early 40s was also influenced by the example that a thriving French sanitary movement provided at the time. ${ }^{62}$ The primary administrative units responsible for the implementation of sanitary 'police' measures in France were various councils, or boards of health. These councils possessed both licensing and enforcement authority in accordance with continental principles of administrative law. Whether British sanitary policy should likewise be placed in the hands of

57 Regarding the analogy between the common law and 'dog-law', Bentham offered the following:

Do you know how they make [the common law]? Just as a man makes laws for his dog. When your dog does anything you want to break him of, you wait until he does it and then beat him. This is the way you make law for your dog, and this is the way judges make laws for you and me. They won't tell a man beforehand.... The French have had enough of this dog-law; they are turning it as fast as they can into statute law, that everybody may have a rule to go by...

(J Bowring (ed) Jeremy Bentham, The Works of Jeremy Bentham (W Tait, Edinburgh 1843) 235).

58 Burns and Innes (n 55) 13.

59 Ibid 15.

60 M Brock, The Great Reform Act of 1832 and the Political Modernization of England (Hutchinson Press, London 1973).

61 E Evans, The Forging of the Modern State: Early Industrial Britain, 1783-1870, $\left(^{\text {rd }}\right.$ edn Longman, London 2001) 293.

62 W Coleman, Death is a Social Disease: Public Health and Political Economy in Early Industrialized France (University of Wisconsin Press, Madison 1982). 
a similar administrative apparatus was the politically volatile question at the heart of early 19 th century British sanitary debates.

The man who led the charge in favour of the continental approach was Edwin Chadwick, a lawyer and close disciple of Bentham, who brought great passion and energy, but limited political skills, to the mission of putting his mentor's legislative principles into practice. Most directly, Chadwick followed Bentham's footsteps in his departure from common law principles through the pursuit of preventive legislative interventions. ${ }^{63}$ Like Bentham, Chadwick considered the French penal codes a model worthy of emulation. ${ }^{64}$ Chadwick was likewise deeply influenced by the newly created judicial and administrative institutions in post-revolutionary France and, most importantly, the French penchant for centralisation. ${ }^{65}$

In France, and through much of continental Europe, the creation of national administrative institutions was seen as a prerequisite to the implementation of social reforms in the decades leading up to and following the French Revolution. The dependence of reform on centralisation was tied to the necessity of overcoming opposition from local political interests and entrenched legal privileges. ${ }^{66}$ British reformers of the time, epitomised by Bentham and Chadwick, similarly equated reform with centralisation. Unlike on the Continent, however, in Britain centralisation cut against what many considered a constitutional commitment to local government. As noted before, in the wake of the 1688 Revolution the British Crown all but relinquished its authority over local matters. In direct contrast with the growth of royal bureaucracies on the Continent, the locus of regulatory power in Britain up till the start of the 19th century was in the hands of local justices of the peace. ${ }^{67}$ Traditionally drawn from the landed gentry, a growing number of these officials from the latter part of the 18th century onward were members of the

63 S Finer, The Life and Time of Sir Edwin Chadwick (Methuen, London 1952) 16.

64 Ibid 17.

65 Thus for example, in an article he published in the Chadwick London Review in 1829, Chadwick offered the following on the French approach to poor relief, and the model it might offer for reform of British law around that time:

We regret that the want of space prevents us giving any details of the system of administration adopted in France for the relief of the poor, but we should fail in our duty, if we did not earnestly recommend it as peculiarly deserving the notice of those who have studied that momentous subject, -our poor laws. We must content ourselves with stating, that the administrations of the funds raised for the relief of the poor are centralized;... Great advantages have already been derived by centralizing the funds, and the several establishments for the relief of the poor.

('A General Medical, and Statistical History of the Present Condition of Public Charity in France' in JB White (ed), 1:2 London Review (London 1829), 536, 561-562. Sir E Chadwick, 561-62.)

66 J Sperber, 'Reforms, Movements for Reform, and Possibilities of Reform: Comparing Britain and Continental Europe' in A Burns and J Innes (eds) (n 55) 315.

67 Webb and Webb (n 29) 351. 
rising manufacturing and merchant class. ${ }^{68}$ 'Unpaid and frequently preoccupied with other matters, including some that must have raised doubts about their impartiality, they often failed to demonstrate a sympathetic and conscientious attitude to their administrative responsibilities. ${ }^{69}$ The result was a pronounced lack of enforcement action against locally influential industrial and other economic interests. ${ }^{70}$ For this reason, Chadwick argued, the time had come for Britain as well to bring sanitary policy under national supervision.

Chadwick promoted the cause of national sanitary reform in his enormously influential Report on the Sanitary Conditions of the Labouring Population of Great Britain (1842). ${ }^{71}$ Recognition of the political necessity of diffusing the tension between his foreign-inspired reform agenda and common law principles led Chadwick to distance and distinguish his own proposals from continental 'police' institutions. Having consulted 'every foreign source he could lay hands on ${ }^{72}$ Chadwick made a point of emphasising that despite the 'striking' success of public health measures instituted under the police model, most notably in Germany, the model was 'scarcely applicable to the substantive English law, or to the early constitutional arrangements in which are found extensive and useful provisions, and complete principles for the protection of the public health.73

In response to the raging and unresolved debate over the causes of disease (and by implication the rationale for state intervention) Chadwick sought to change the subject to practical engineering solutions to the evident filth and stench of Victorian cities. 'The medical controversy as to causes of fever', Chadwick wrote in his Report, 'as to whether it is caused by filth and vitiated atmosphere, or whether the state of the atmosphere is a predisposing cause to the reception of the fever... does not appear to be one that for practical purposes need be considered, except that its effect is prejudicial in diverting attention from the practical means of prevention. ${ }^{74}$ The argument was in opposition to a central premise of the reactive common law regime: the insistence on proof of cause and effect relationships between a regulated behavior and identifiable harm. Within this framework, scientific uncertainty on the causes of disease was a significant barrier to the implementation of available pollution control measures. The ability to circumvent this evidentiary impasse accounted for the appeal of the continental approach to Chadwick and other British sanitary reformers of the time.

71 Chadwick (n 65) 561-62.

72 Finer (n 63) 209.

73 Chadwick (n 65) 348.

74 Ibid 214 (emphasis added). 
A similar willingness to relinquish proof of injury to health in favour of a focus on technical solutions characterised the work of a Parliamentary Select Committee convened in 1843, under the chairmanship of WA Mackinnon, a Scottish MP and a Chadwick ally, to inquire into the 'Means and Expediency of preventing the Nuisance and Smoke arising from Fires or Furnaces'. As evident from its title, the Committee's primary concern was the 'means and expediency' of smoke prevention and not the justification for preventing smoke in the first place. Over 16 hearings the Committee heard testimony from chemists, engineers, manufacturers and proprietors of steam engines and various ingenious persons who had devised means and taken out Patents for the Prevention of Smoke. ${ }^{75}$ All were asked to focus their testimony on three interrelated questions. The first pertained to practicability of available means for preventing or diminishing smoke. The second applied to the advisability of compelling manufacturers to adopt any such means. And the third examined the political expediency of legislation geared at smoke abatement. Having concluded from the evidence put before it that smoke could be feasibly controlled through available technological means, the Committee concluded its report with the recommendation that Parliament take up a bill prohibiting the production of smoke from furnaces and steam-engines. When the government balked at this recommendation, Mackinnon himself unsuccessfully presented a bill along these lines in $1844 .^{76}$ His efforts over the next five years yielded six additional smoke bills, all of which were ultimately defeated. ${ }^{77}$ The failure was in part attributable to the absence of clear proof that smoke injured health. ${ }^{78}$ Mackinnon's attempt to frame the debate in reference to the practicability of control, rather than scientific proof of harm, proved insufficient to the task.

A modest legislative step in the direction of technology-based control was nonetheless taken under the Metropolitan Buildings Act of $1844,{ }^{79}$ passed in response to Chadwick's report and a subsequent Royal Commission Report on the Health of Towns. The Act prohibited the establishment of new offensive or noxious businesses in London at a distance of less than 40 feet from any public way, or less than 50 feet from dwellings. In tandem, the Act set a limit of 30 years for the operation of existing noxious business at less than the distances specified. Importantly, however, where such businesses were able to demonstrate deployment of 'all the means then known to be available for mitigating' their effects, Section 26 of the Act authorised justices to exercise leniPrevention together with the minutes of evidence appendix and index' HC (1843) 583.

76 Ashby and Anderson (n 12) 10.

77 Ibid 11.

78 Ibid 14.

79 Metropolitan Buildings Act 1844 (7 \& 8 Vict c 84). 
ency, creating in this fashion a judicial, licensing-like, mechanism for the implementation of available means of pollution control.

Four years later, in the Public Health Act of $1848,{ }^{80}$ Parliament settled on an 'uneasy compromise' between proponents of centralised sanitary reform and defenders of common-law-based local institutions. ${ }^{81}$ The Act provided a code-like regulatory template for local sanitary governance, which included provisions for the construction of sewers, drainage and water and gas supplies, burial grounds and nuisance abatement. In what appeared like outright adoption of continental licensing, the Act subjected the establishment of noxious or offensive trades to the authorisation of local boards of health. ${ }^{82}$ This requirement was coupled with authority on the part of the local board to enact by-laws regulating the operation of such newly established noxious trades in order to prevent or diminish the noxious or injurious effects thereof', ${ }^{83}$ Unlike the situation on the Continent, where preventive sanitary regulation was imposed as a matter of course, the provisions of the Public Health Act were to be made applicable to any particular locality only in response to a petition from one-tenth of its rate-paying inhabitants and a subsequent hearing of locally interested parties. The one exception where localities could be coerced into the Act's regulatory regime pertained to areas where the annual death rate exceeded 23 per thousand. ${ }^{84}$

The Public Health Act fell short of Chadwick's vision in the Sanitary Report not only in that it left most localities free to choose whether to accept or reject its terms, but also in its reluctance to rely on administrative bodies that would directly challenge local interests. Thus, whereas Chadwick's plan called for placing local sanitary authority in the hand of crown-appointed boards, the Act ultimately empowered elected municipal bodies for this purpose. In similar fashion Chadwick's recommendation that local boards be subject to centralised legal, financial and engineering oversight via the supervision of the Judicial Committee of the Privy Council, was rejected in favour of endowing a newly created central board of health with limited supervisory authority. $^{85}$

Other than the authority to impose the Act under the circumstances described above, the central board exerted some control over the dismissal of local surveyors, the approval of engineering projects and the capacity of local boards to borrow money for the purpose of financing these projects. ${ }^{86}$ An article published in Britain shortly before the Public Health Act was signed into

80 Public Health Act 1848 (11 \& 12 Vict c 63).

81 Evans (n 61) 364.

82 Public Health Act 1848 s LXIV (11 \& 12 Vict c 63).

83 Ibid.

84 Public Health Act 1848 s VIII (11 \& 12 Vict c 63).

85 R Lambert, Sir John Simon and English Social Administration (Macgibbon \& Kee, London 1963) 65.

86 Finer (n 63) 319. 
law characterised the division of authority between central and local government under the Act in the following way: '[i]n the actual administration of the act, little or nothing is assigned to the Central Board. The power is almost entirely in the hands of the Local Board... And as the local Boards are popularly selected, the power of putting the act in force ultimately belongs to the great body of inhabitants of the districts affected'. ${ }^{87}$ The same article then went on to contrast British sanitary institutions, even subsequent to the Public Health Act, with those that prevailed on the continent where the 'power of enforcing measures for public health, is vested almost exclusively in central or government boards. ${ }^{88}$ Notably, the author attributed the observed differences between British and continental sanitary regulation to a fundamental divergence in underlying conceptions of state authority:

A curious chapter in the history of the internal economy of states is that which the various sanitary provisions adopted under different forms of government, Nations working for the same end, the public health, seek it by entirely different means. On the Continent, where the rights and liberties of individuals seldom constitute a serious obstacle to State purposes, the most stringent sanitary regulations have long existed and the surveillance of police, which is almost unknown in England, constitutes the principal means of effecting them. Here, the public jealousy of state interference, and a sensitive regard for the rights of property, have long prevented the institution of a general organized sanitary system. ${ }^{89}$

This divergence, as touched upon earlier, traced to the constitutional struggles of the 17th century and the subsequent decentralisation of British economic regulation. The legitimacy of civil-law modelled regulatory institutions such as royal proclamations and conciliar courts such as the Court of Star Chamber was the essential constitutional question in dispute during that era. The claim that common law principles barred the introduction into England of civil law instruments of this type dates at least as far as the 15th century writings of Sir John Fortescue. ${ }^{90}$ The barrier followed for Fortescue from the common law's rejection of the absolutist authority which the Civil Law was said to confer under the Justinian maxim '[w]hat please[s] the prince has the force of law. ${ }^{91}$ Sir Edward Coke and other leading common law theorists built on this line of argument in their opposition to the 'civilian' Stuart monarchy. The Revolution marked the ascendance of common law ideology and

1997) 17.

91 Ibid. 
seemingly confirmed the unconstitutionality of civil law-based regulatory institutions. Notwithstanding this, throughout the 18th and early 19 th centuries, reformers of various stripes sought to introduce continental modelled administrative initiatives, as discussed before. Advocates of these foreign-inspired projects, such as Bentham, were regularly charged with mounting attacks leveled against the very heart of the English constitution, ${ }^{92}$ With added force the same line of argument encountered, and ultimately helped derail, the Public Health Act, as discussed below.

\subsection{Anti-Centralisation and 'Local Self-Government'}

Among the Public Health Act's most vocal opponents was a barrister by the name of Joshua Toulmin Smith. A prolific and indefatigable crusader for 'local self-government', Toulmin Smith set out to mobilise public opinion against the encroachment of centralised continental regulatory institutions, which the Public Health Act in his eyes epitomised. Toulmin Smith had no quarrel with the importance and legitimacy of public health measures. But he insisted that any such measures must be based on '[i]nstitutions of true Local SelfGovernment' that is, in accordance with common law. ${ }^{93}$ Where public health protection was concerned, the pertinent and wholly sufficient regulatory institution was nuisance law. For Toulmin Smith the superiority of nuisance law followed from the burden of proof it imposed upon those who sought protection against injury from others. In his words, the common law, 'most wholesomely throws it upon those who allege any particular thing or course of proceeding to be inconsistent with the health of any neighbourhood, or its welfare in any respect, to bring forward the proof, before the people themselves, that it is as alleged. ${ }^{94}$ In this fashion, the common law ensured that public health interventions will proceed only out of 'true regard for public welfare' rather than 'specious disguise' aimed at gaining 'some interested object' or 'crude individual notions'. What made this evidentiary requirement a cornerstone of English constitutionalism for Toulmin Smith was the protection it offered against ill-intentioned interferences with property and liberty under specious health and safety justifications. In contrast, it was the ability to bypass judicial scrutiny of this type that explained for Toulmin Smith the favour Centralization finds in the eyes of interested schemers. ${ }^{95}$ The 'so-called 'Public Health Act' of 1848 ' wrote Toulmin Smith, had as its 'object to reduce all places into a state of abject subjection and subserviencey; to impose upon them enormous and lasting burthens which shall completely tie up their

92 J Redlich, in FW Hirts (ed), Local Government in England (Macmillan \& Co, London 1903) 145.

93 J Toulmin Smith, Local Self-Government and Centralization (Chapman, London 1851) 115.

94 Ibid 115.

95 Ibid 115. 
hands to fasten a horde of functionaries upon the land; and to loosen all the foundations of Law and Property. ${ }^{96}$

The connection between localism and self government followed for Toulmin Smith from the intersection between two defining historical features of local administration in England. The first was the reliance of traditional local institutions such as the Parish and the County, on unpaid, lay officials rather than continentally inspired 'Commissioners' and 'Inspectors. ${ }^{97}$ The second was the judicial, and hence reactive, procedures through which English local government ruled. In this, English local government accorded with what Smith posited as 'fundamental rule of the English constitution: '[a]ll Law must spring from the people and be administered by the people. ${ }^{98}$ Centralisation, in contrast, served for Toulmin Smith as an umbrella under which he lumped the various ills of continental administration, or in his preferred formulation 'foreign centralized system of Police. ${ }^{99}$ The central message Toulmin Smith expounded throughout his writings was that the continental model was not only inferior to 'local self-government' but unconstitutional by virtue of its deviation from common law principles.

The influence of Toulmin Smith's ideas is evident in the constitutional line of arguments put forth in opposition to the Act in the parliamentary debates leading up to the legislation. Thus for example, in May 1848 a Tory MP by the name of David Urquhart denounced the Public Health Bill as "un-English and unconstitutional-corrupt in its tendency-it was an avowal of a determination to destroy local self-government, and, if carried, its effect would be to pass a roller over England, destroying every vestige of local pre-eminence, and reducing all to one dull and level monotony'. In what may well have been a direct quotation from Toulmin Smith, Urquhart then went on to note that anyone who would take the trouble to refer to Blackstone's Commentaries would find that the common law provided ample means for putting down all the nuisances to which this Bill referred. The Bill was in this respect useless; the common law provided an ample remedy; and if the remedy provided by the common law were not applied, it was solely owing to our own neglect: ${ }^{100}$

The strong opposition which the Public Health Bill encountered in and out of parliament forced a legislative compromise whereby the authority of the general board of health was significantly weakened relative to the more rigorous oversight powers that Chadwick's plan intended to confer on the Board at the start. A crucial concession made in this regard was the large amount of discretion the Act left local authorities both with respect to whether to accept

96 Ibid 207.

97 J Toulmin Smith, Government by Commissions: Illegal and Pernicious (S Sweet, London 1849) 295.

98 Toulmin Smith (n 93) 21.

99 Ibid 204.

100 Hansard HC vol 98 col 710-43 (5 May 1848). 
the Act's jurisdiction in the first place and regarding its implementation subsequent to that. For its part the General Board possessed few enforcement powers of its own. ${ }^{101}$ Moreover, once established, the Board proved reluctant to invoke the limited coercive tools available to it under the Act, most importantly the authority to impose the Act on localities with high death rates. ${ }^{102}$ At the same time, to the degree that the Act invigorated local enforcement against pollution sources and other public nuisances, the General Board (which frequently upheld such local actions) became a lightning rod for criticism from those whose economic interests were on the line. ${ }^{103}$ Chadwick's authoritarian personality and political insensitivity further added to the Board's unpopularity. ${ }^{104}$ Chadwick personally, and the Board of Health more generally, were irrevocably associated in the process with 'alien despotism'. ${ }^{105}$ By 1854, Chadwick, together with the other two members of the Central Board, were forced to resign, a moment that marked the end of Chadwick's career in public life. The person who would take his place as the leading public health reformer and administrator was Dr John Simon.

Simon-who would go on to occupy a series of senior positions in sanitary administration - was appointed to the Central Board of Health in 1855. The appointment was due to the efforts of Sir Benjamin Hall, who assumed the presidency of the Central Board in $1854 .^{106}$ Hall was a vehement opponent of Chadwick and a devotee of local government, whose appointment to the Board was celebrated by the anti-centralisation movement. ${ }^{107}$ For Hall, the absence of a Medical Officer on the Central Board until then was indicative of the undue weight that Chadwick and his allies ascribed to technical and engineering capacity, rather than medical analysis of the causes of disease. ${ }^{108}$ The appointment of John Simon to the Board ushered in a transformation in this respect.

Simon took from Chadwick's political demise clear-cut lessons on the ideological barriers impeding direct transplantation of continental sanitary institutions to Britain. Determined to avoid the taint of 'centralisation', Simon was reluctant to impinge on local autonomy and sought to secure the cooperation of localities through persuasion rather than coercive interventions. ${ }^{109}$ The shift is a testament to the influence of 'Local-Self Government' ideology during the 1850s. Evidence that for Simon this shift was at least partially the

$101 \mathrm{U}$ Henriques, Before the Welfare State: Social Administration in Early Industrial Britain (Longman, London 1979) 138.

102 Ibid 140.

103 Ibid 144.

104 D Porter, Health, Civilization and the State: A History of Public Health from Ancient to Modern Times (Routledge, London 1999) 126.

105 Lambert (n 85) 222.

106 Ibid 229.

107 Ibid 222-23.

108 Ibid 229.

109 Ibid 264. 
result of ideological conviction rather than strict political calculation, can be found in retrospective discussion of this era in his book English Sanitary Institutions. ${ }^{110}$ There Simon applauded the 'new spirit' which the Presidency of Sir Benjamin Hall brought to the Central Board whose 'tenure of office...tended importantly to bring into vogue the better conceptions which had then begun to declare themselves, and which from then till now have been of growing influence in this country, as to the proper limits of central authority in relation to affairs of local government.' ${ }^{111}$ In a footnote he also noted Toulmin Smith's strong and learned constitutional argument against '[t]he former system.'

The element that defined Simon's approach to sanitary administration, and distinguished him from Chadwick, was the foundational role he ascribed to medical science within public health policy. As discussed, Chadwick was far less interested in the exact causal link between filth and disease than he was in the implementation of practical solutions to specific sanitary problems. John Simon, in contrast, put scientific investigation at the heart of the sanitary enterprise, beginning with the publication of his Papers Relating to the Sanitary State of the People of England in 1858. The core of the Sanitary Papers consisted of statistical mortality figures and the distribution of various diseases across multiple locations in Britain, revealing in the process drastic fluctuations, consistent with differences in residential and industrial conditions, in rates of fatal diseases. ${ }^{113}$ Simon contributed an introduction in which he elaborated on the lessons these findings suggested on the preventability of disease and the proper administration of sanitary reform. ${ }^{114}$ However, in keeping with the anti-centralisation sensibilities of the times, Simon professed his faith in the capacity of scientific information to spur local authorities into voluntary action. In contrast to the coercive functions Chadwick's model envisioned for central government, Simon viewed the provision of expert and impartial scientific information on the causes of disease as the core sanitary task of central government. $^{115}$

The Sanitary Papers inaugurated a new era of 'preventive medicine' that successfully diffused much of the antagonism that Chadwick's 'sanitary engineering' earlier precipitated. The favourable reception could perhaps be attributable in part to the fit between the emphasis on scientific inquiry and the foundational common law principle conditioning regulatory interventions on proof of harm. Chadwick deviated from this principle in his preoccupation with technical solutions to evident stench and filth in advance of clear

110 Sir John Simon, English Sanitary Institutions: Reviewed in Their Course of Development and in Some of Their Political and Social Relations ( ${ }^{\text {nd }}$ edn John Murray, London 1897).

111 Ibid 237.

112 Ibid.

113 Lambert (n 85) 262.

114 Ibid 263.

115 Ibid 265. 
understanding of the mechanism through which these threatened health. Consequently, the shift from sanitary engineering to preventive medicine served, to some degree, to realign mid-19th century British sanitary policy with common law principles. This point bears emphasis due to its potential relevance for understanding the common law roots of the scientific orientation that characterised the British approach to regulation at the end of the 20th century.

Where the regulation of noxious fumes in the years leading up to the Alkali Act is concerned, the attempt after 1854 to cast legislation in more 'common law friendly' terms is best evident in The Nuisances Removal and Diseases Prevention Act. ${ }^{116}$

The product of Sir Benjamin Hall's single year as President of the Central Board, the Nuisances Removal Act appears to have been geared at the implementation of available technological means for ameliorating sanitary health hazards, and as such was consistent with Chadwick's sanitary engineering approach. The Act adapted this model to the reactive logic and evidentiary demands of the common law, however, by conditioning any such technologydirected intervention on a two-step proof of injury. Under the Act, local authorities could bring complaints before local justices of the peace, but only upon certification by a medical officer, or two medical practitioners, that the condition in question constituted a nuisance, or injury to health. Next, the justices were to inquire themselves into the allegations and were authorised to impose fines on the owners of offending premises only to the extent that they were themselves persuaded of the existence of such injury. The political sentiments behind this requirement were made clear in a treatise, first published soon after the passage of the Act, whose writer noted with satisfaction the Act's insistence on proof of injury and contrasted it with earlier legislation which, out of an over abundance of concern for public health, justified 'enactments containing enormous arbitrary powers. ${ }^{117}$ It was for the purpose of preventing 'the abuse of these powers' that the same author went on to note that the checks provided by the statute now under discussion were interposed. ${ }^{118}$

Presented with the necessary proof, local justices were authorised under the Act to impose fines ranging from five pounds for a first offence to 200 pounds maximum for repeated offences. But as the Act explained under section 28 which dealt with effluvia from noxious trade, fines could be assessed only against businesses that failed to deploy 'the best practicable means for abating such nuisances or preventing or counteracting such effluvia'. Furthermore, under the latter circumstance, justices were authorised to

116 Nuisances Removal and Diseases Prevention Act 1855 (18 \& 19 Vict c 121).

117 D Deady Keane, The Nuisances Removal and Diseases Prevention Acts, with Introductory Comments, Cases, and Forms (5 ${ }^{\text {th }}$ edn Shaw and Sons, London 1866) 9.

118 Ibid 9-10. 
suspend the fines 'upon condition that the person so complained against shall undertake to adopt, within a reasonable time, such means as the said justices shall judge to be practicable and ordered to be carried into effect for abating such nuisances, or mitigating or preventing the injurious effects of such effluvia. The goal of the Act was, as such, to spur the implementation of available sanitary improvement measures, much like the continental sanitary model which Chadwick and others sought to import. But, whereas the continental model (adopted with respect to noxious trades to some degree by the 1848 Public Health Act) relied on proactive licensing requirements, the Nuisances Removal Act, in accordance with the common law's reactive approach, stepped in only once as an injury materialised.

In this respect the 1855 Nuisances Removal Act departed not only from the Public Health Act, but from an Act requiring the abatement of smoke in the London Metropolis which Parliament passed two years before. ${ }^{119}$ As noted earlier, ${ }^{120}$ a Parliamentary Select Committee concluded in 1844 that the technological means needed to consume smoke were available and feasible, and unsuccessfully recommended legislation that would have required operators of furnaces to prevent emissions of smoke. A number of subsequent legislative initiatives along these lines similarly failed, including an amendment by the House of Lords that sought to include provisions dealing with smoke abatement within the Public Health Act of 1848. The absence of clear evidence linking exposure to smoke with injury to health was among the chief reasons cited against the inclusion of a smoke abatement clause in the 1848 Act. The perspective of supporters of smoke abatement since the McCormick committee's 1844 report was that uncertainty on health effects should not impede the implementation of available means. But this view was unable to overcome the opposition of those in Parliament who held to the view that '[t]he only justification for such a [smoke clause] was, that smoke had an effect on the public health'. And that '[i]t ought not too hastily ... be presumed that what were called nuisances were necessarily injurious to health. ${ }^{121}$

The Smoke Nuisance Abatement Act that Parliament finally passed in 1853 was restricted to the London Metropolis. Its passage is credited to the efforts of Lord Palmerston, who during his less than three years as Home Secretary (1852-1855), added smoke abatement to the list of social reform causes to which he lent his energy. ${ }^{122}$ The operative clause in Palmerston's smoke law required that smoke from industrial furnaces "be constructed or altered so as to consume or burn the smoke. The law threatened operators of smoky furnaces with fines that were to increase with subsequent offences and delegated enforcement authority to metropolitan police commissioners who were to

119 The Smoke Nuisance Abatement (Metropolis) Act 1853 (16 \& 17 Vict c 128).

120 See nn 72-73 above and accompanying text.

121 Hansard HC vol 100 cols 1173-80, 1179 (7 August 1848).

122 D Roberts 'Lord Palmerston at the Home Office' (1958) 21 Historian 63, 65. 
bring violators before the courts. Determined to see that the Act would not become a dead letter, Palmerston actively prompted the police into action and had the Crown counsel press for maximum fines. ${ }^{123}$ Notably, the demand for smoke abatement, under Palmerston's law, was independent of proof of injury to health or even an annoyance and, as such, closer in spirit to the continental approach.

Lord Palmerston's evident plans for future legislative initiatives along this line prompted his request for the earlier discussed Lewis Report on French regulation of noxious trades. ${ }^{124}$ By the time Dr Waller Lewis completed his report in 1855, Palmerston had left the Home Office to become Prime Minister. Instead, it was Lord Derby, the once and future conservative Prime Minister, who would end up citing from Lewis's Report while calling for Parliamentary investigation into pollution from Alkali manufacturing. Lord Derby justified his call for legislative intervention through three arguments. The first was the scope of property and other damage which the 'poisonous gases' inflicted on surrounding lands. The second was the evidentiary obstacles that the common law placed before plaintiffs who looked to it for relief. And the third, and arguably most important, was the availability of what he described as 'a most perfect and complete remedy' at least where the problem of Alkali pollution was concerned, as will be seen below. Lord Derby credited those manufacturers who already made use of this technology with excellent results, but noted with regret that others failed to take 'the same precautions' due to the difficulties associated with bringing successful actions under common law. ${ }^{125}$

\section{Forging a Hybrid British Approach: The Alkali Act (1863-1884)}

Within seven days of Lord Derby's speech, a House of Lords Select Committee on Injury from Noxious Vapours was appointed and began hearing witnesses. $^{126}$

\subsection{From the House of Lords Select Committee to the Alkali Act}

The Select Committee hearings concerned a long list of industrial processes and harmful gases, and did not focus as such on Alkali manufacturing. Testimony revolved around three key issues. The first pertained to the scope of the injury to property and impact on health associated with the gasses.

123 Ashby and Anderson (n 12) 18.

124 See nn 18-20 above and the accompanying text.

125 Hansard HL vol 166 col 1460 (9 May 1862).

126 Ashby and Anderson (n 12) 21. 
The second inquired into available mitigation measures with respect to various gasses and processes. And the third concerned deficiencies in the regulatory regime governing noxious vapours under existing legislation and examined potential alternative regulatory approaches.

On the injury side there were mountains of testimony attesting to the devastation the fumes inflicted on vegetation and the discomforts, even suffering, it brought to humans, though whether the fumes actually endangered health could not be resolved. In an effort to establish the inadequacy of existing legislation, numerous witnesses recounted a long list of evidentiary and financial impediments to successful nuisance indictments. An additional obstacle followed from the fact that in order to enter facilities, inspectors required permission from local judges, undercutting the incentive for industrialists to ensure that their facilities were taking pertinent pollution prevention measures at all times. Testimony supported the availability and effectiveness of such measures across a variety of industries, but nowhere more so than with respect to hydrochloric acid emissions from the alkali industry. Because hydrochloric acid was soluble in water, it was amenable to condensation by allowing it to percolate through pieces of coke that were subject to a slow stream of water. A device built on this principle was first patented in 1836, and a number of Alkali manufacturers made use of it with good results. But others failed to do so in the absence of sufficient regulatory incentive. But by the time of the Select Committee hearings, there existed a near consensus, shared not only by scientists, but by the manufacturers as well, 'that it is not only possible, but perfectly easy, with due care, to carry on the manufacture without causing any perceptible injury to the neighbourhood. ${ }^{127}$

The Report, which the Select Committee presented in August 1862, offered two sets of recommendations. The first pointed out desired changes in the existing legislation with respect to noxious trades, while the second recommended the passage of specific legislation directed at the creation of a specialised law dealing with 'alkali and other chemical works of a like description. ${ }^{128}$ In this the Committee followed the recommendation of Dr Lyon Playfair, a respected chemist and sanitarian. Describing soda manufacturing (by alkali manufacturers) as 'the monster nuisance of all' and noting the ready availability of control technology, Playfair ventured the opinion that 'it might be better not to legislate generally for smaller matters when there is a large subject, like the soda manufacture, which could at once be dealt with. ${ }^{129}$ Perhaps more importantly, as the Committee indicated in its report, the recommendation for specialised alkali legislation concurred with the view

127 Select Committee on Injury from Noxious Vapours, 'Injury from Noxious Vapours' HL (1862) 486 [7].

128 Ibid 9.

129 Select Committee on Injury from Noxious Vapours (n 127) [1137]. 
of "the manufacturers engaged in those trades, that they ought to be dealt with by special legislation, ${ }^{130}$

Where changes to existing nuisance abatement legislation were concerned, the Committee noted the great desirability of consolidating and making uniform throughout the country the patchwork of nuisance laws existing at the time. ${ }^{131}$ Barring that, the Committee recommended a number of measures geared at strengthening the administrative authority of local nuisance inspectors. Most importantly, these included allowing medical inspectors free access 'to all works productive of noxious vapours at all hours when such works are in operation, and that defendants no longer be allowed to decline the jurisdiction of local magistrates and remove cases to the superior courts, and that appeals to superior courts will be restricted to instances where the pertinent magistrate certifies the existence of questions of law appropriate for such an appeal. ${ }^{132}$ Taken together, these recommendations sought to move nuisance enforcement closer to the continental administrative model, most importantly through limits on the oversight functions of regular courts.

With respect to alkali manufacturers, the Committee recommended special legislation that, without prescribing any specific process, imposed a substantial penalty on the emission of sulphuric acid and ammonia alum, as well as hydrochloric gases from alkali works. ${ }^{133}$ Departing from the local enforcement processes employed under existing laws, the Committee emphatically recommended that enforcement in this case be made the task of central government inspectors 'wholly independent of all local control, and removed, as far as possible, from all local influence. ${ }^{134}$ But the Committee's most far-reaching recommendation conferred the ability to sue for penalty under the law on 'any person' at quarter sessions, with appeal to superior courts limited to the same magistrate certification as above. ${ }^{135}$

The legislation that ultimately passed Parliament as the Alkali Act of 1863 followed the Committee's recommendation with respect to the focus on alkali manufacturing and the creation of a centralised inspectorate (but postponed regulation of sulphuric acid and ammonia alum to a later date). ${ }^{136}$ Refraining from specifying the type of control technology to be used, the law imposed an emission standard requiring that $95 \%$ of the hydrochloric acid be removed from the flues coming out of the stacks of alkali manufacturers. ${ }^{137}$ The recommendation to allow 'any person' to sue for penalties was not endorsed. Instead, the Government Bill initially placed enforcement directly with the

130 Ibid 9.

131 Ibid 8.

132 Ibid 9.

133 Ashby and Anderson (n 12) 23.

134 Select Committee on Injury from Noxious Vapours (n 127) 9.

135 Ibid 9.

136 Ashby and Anderson (n 12) 23.

137 Ibid 23. 
inspectors. In response to protest from the manufacturers, the final legislation authorised inspectors to sue for penalties through civil litigation before county courts subject to unlimited appeals. ${ }^{138}$ Most importantly, however, the Act relegated enforcement to a specially created Alkali Inspectorate, under the direction of the Board of Trade. In this, Parliament concurred not only with the Committee but with the majority of the alkali manufacturers who favoured special legislation and a centralised inspectorate over subordination to local authorities.

The Alkali Act passed as a consequence with the tacit or explicit support of the industry whose interests the law served to a large extent. To begin with, the law created an even playing field within the industry where, up until then, plants that had condensed their gases were potentially disadvantaged relative to competitors that did not. More importantly perhaps, the law appears to have conferred de facto protection against common law liability, notwithstanding the explicit retention of common law rights under the Act of $1874 .^{139}$ In contrast to the common law's purported absolutist protection against proven injury, the Alkali Act more modestly aimed at incremental relief through the implementation of feasible means. AE Fletcher, who served as the second Chief Inspector of the Alkali Inspectorate, reflected in 1892 in the following words on the novelty inherent to the Act's approach:

[T]he Alkali Works Regulation Act of 1863, was, as far as I have been able to discover, a new departure in the legislation not only of this but of any other country. Prohibition of noxious trades there have been, and, local Acts to regulate the locality of factories where noxious trades were carried on; but there had been before 1863 no Act of the Legislature whereby an admission was implied that the emission of noxious gases was in certain cases unavoidable, and that such would be subject to definite regulations. The Act of 1863 recognised the existence of alkali works, and the fact that acid gases liable to injure surrounding vegetation were discharged from them. There was not attempt to put a stop to such works on account of the admitted injury they were liable to inflict on the neighbourhood, but steps were taken to limit that injury, and to oblige the manufacturers to adopt means for reducing the evil to the smallest possible amount. I think I am right, therefore in saying that in this Act a new principle was thus introduced, one differing widely from that of simple repression, hitherto applied whenever an admitted evil of the kind was dealt with. ${ }^{140}$

138 MacLeod (n 10) 85; Ibid.

139 B Pontin, 'Tort Law and Victorian Government Growth: The Historiographical Significance of Tort in the Shadow of Chemical Pollution and Factory Safety Regulation' (1998) 18 OJLS 661, 663.

140 AE Fletcher, 'Modern Legislation in Restraint of the Emission of Noxious Gases from Manufacturing Operations' (1892) 11 J Soc Chem Indus 120. 
The principle to which Fletcher alluded was implicit to the continental licensing regime under which authorisation was often contingent on the deployment of mitigation measures, not the elimination of injury. The approach was first introduced into British law under the various earlier-cited legislative provisions allowing the use of best practicable means as a defence against penalties for the creation of nuisances. But since the decision on the meaning of best practicable means was left to local authorities under those laws, industrial actors could face multiple and inconsistent control requirements across locales. This was the problem that centralised inspection was intended to solve, in similar fashion to the role of the central authorities that oversaw the regulation of industrial processes on the Continent.

The Alkali industry's consent was what allowed the creation of a centralised regulatory regime, during an era marked by pronounced anti-centralist sentiments of the type that undermined Chadwick's public health campaigns. The centralised inspection incorporated into the Alkali Act built on a model dating to the 1833 Factory Act, which prohibited the employment of children for more than 12 hours a day, and created a special inspectorate with authority to enter premises and apply legal sanctions. Ambivalence over the propriety of centralised enforcement of this type was evident, however, from the start, with some of the inspectors adhering to the view that prosecution was a weapon of last resort and that persuasion, rather than coercion, was the primary tool of the Inspectorate. Rooted in part in the political need to secure the cooperation of powerful manufacturers, the conciliatory approach became the mark of centralised inspection over the course of the 19th century. ${ }^{141}$ For the Alkali industry, the conciliatory reputation of existing central inspectorates was likely a consideration behind the industry's preference for central inspection. If on the Continent the benefits associated with uniform standards and protection from the potential idiosyncrasies of local regulation came at the cost of coercive state intervention, the Alkali Act had the potential of delivering many of the benefits of centralisation in a more industry-friendly fashion.

The option of adopting the continental licensing model was explicitly advocated by at least two of the witnesses who appeared before the Noxious Vapours Select Committee. The first was WH Michael, who earlier served as mayor of the borough and chairman of the Board of Health at Swansea. Asked whether he had given thought to possible alterations in the existing law, Mr Michael specifically offered the districting approach 'adopted in foreign countries'. Mentioning France and Hamburg as specific examples, Michael recommended two practices. The first consisted of restricting the location of new polluting industries 'to certain places, where damage has been already done'.

141 G Rhodes, Inspectorates in British Government: Law Enforcement and Standards of Efficiency (Allen and Unwin for the Royal Institute of Public Administration, London 1981) 64. 
The second was a requirement that 'manufacturers should use the best known means for preventing injury.'142

In the same vein, though without direct mention of the Continent, a medical officer and clerk to the Board of Health from London's Poplar District offered the licensing requirements governing slaughter houses under the Metropolitan Market Act of 1857 as a model:

$[\mathrm{O}]$ ne of the suggestions which I proposed to offer to the consideration of your Lordships, that those factories should not be permitted to go on, unless under license, or something of that sort, as in the case of the slaughter-houses, the licenses for which are renewable annually; and the owners give the local authority one month's notice of their intention to apply to the petty sessions, so that the local authority may oppose the application, if they see fit. ${ }^{143}$

The same witness went on to recommend that licenses be renewed annually, since it is possible that their plant may be out of order, and from the disorder of their plant the nuisance may arise. ${ }^{144}$ The possibility of emulating the continental licensing model seemingly received little serious consideration from the Select Committee, but its report began its discussion of the existing state of law pertaining to noxious vapours with a reference to the fact that, "with the single exception of the provision in the Public Health Act... no previous sanction is required, as in some other countries, for the establishment of works likely to produce nuisances. ${ }^{145}$ Proposals for Britain to adopt a similar licensing approach recurred throughout the first decades of the Alkali Inspectorate, as the following section recounts.

\subsection{Regulating in the Shadow of the 'Preventive System' of the Continent: the Alkali Inspectorate under Robert Angus Smith}

The distinct regulatory style that would remain true of the Alkali Inspectorate for over a century was largely the product of the policies pursued under $\mathrm{R}$ Angus Smith, who served as Chief Alkali Inspector from 1864 until his death in $1884 .^{146}$ His tenure was marked by continuing debate over the desirability and legitimacy of continental licensing approaches to pollution regulation.

Smith completed a doctorate in chemistry in Germany, subsequent to which he served as an assistant to the Health of Towns Commission appointed

142 Select Committee on Injury from Noxious Vapours (n 127) [626].

143 Ibid [2179].

144 Ibid [2183].

145 Ibid 5.

146 MacLeod (n 10) 97, 104, 109; C Garwood, 'Green Crusaders or Captives of Industry? The British Alkali Inspectorate and the Ethics of Environmental Decision Making, 1864-95' (2004) 61 Ann Sci 99. 
in 1843 in response to Chadwick's Sanitary Reports the year before. While acting in that capacity, Smith became acquainted with Chadwick as well as other prominent sanitarians, whom he mentioned favourably in subsequent writings. ${ }^{147}$ MacLeod described Smith as 'something of a protégé of Chadwick' but was also careful to note that while 'Smith knew and admired Chadwick' there was little evidence to suggest that he shared Chadwick's Benthamite ideology. ${ }^{148}$ Still, the formative years of Smith's career put him in close touch with continental regulatory principles, both because of the time he himself had spent in Germany, and through his exposure to Chadwick's ideas. The degree to which these principles shaped Smith's regulatory view is difficult to tell, partially because of the lessons that Chadwick's failures imparted on the hazards of aligning oneself with a continental-inspired reform agenda. The primary sources shedding light on Smith's philosophy as Chief Inspector are the detailed annual reports he submitted to Parliament. In analysing the discussion of the benefits and drawbacks of licensing across a number of his reports, it is important to keep in mind that these were for all intents and purposes public relations documents, and that Smith must have been aware of the imperative of framing his message in politically palatable ways.

Smith first broached the topic of licensing in his third report, covering the Inspectorate's activities in 1866. In what would be his strongest statement in support of licensing Smith noted in that report that both the public and industry stood to benefit from a requirement for pre-authorisation:

If it were generally demanded that no factory should be put up on any spot, with certain exceptions or within certain limits, without the sanction of the constituted authorities, which may be those of the district, the public would find fuller protection provided in such cases; when permission was given, the authorities could not assist anyone to object to the works if they were conducted according to the standard of purity. ${ }^{149}$

Smith's report the following year was clear on the extent to which the option of adopting a continental licensing approach continued to excite debate. Notably, in contrast to his seeming endorsement of licensing the year before, this time around Smith adopted a more neutral stance:

As considerable interest has been excited regarding the mode of dealing with chemical works, and French, Belgian, and German law blamed and eulogized, without sufficient reason, I think it will be well to give here

147 A Gibson and WV Farrar, 'Angus Smith, FRS and 'Sanitary Science”(1974) 28 Notes Rec R Soc 241, 242; JM Eyler, 'Conversion of Angus Smith: The Changing role of Chemistry and Biology in Sanitary Science, 1850-1880’ (1980) 54 B Hist Med 216, 217.

148 MacLeod (n 10) 91.

149 Inspector of Alkali Works, 1866 Third Annual Report (London 1867) 53. 
some of the points which seem to be most interesting to us. There is something both to learn and to avoid. ${ }^{150}$

Having thus distanced himself from the position of either side in this debate, Smith devoted the following 26 of the 115 pages in the main body of his report to detailed discussion of the regulation of noxious trades in France, Belgium and the Netherlands, much of it drawn, or directly quoted, from the earlier discussed treatise by Jules Vilain. He added some observations based on his own travels to the Continent, and concluded with a statement suggesting that the continental approach failed to produce the expected result: "[m]y belief is that, comparing the attempts to legislate with the result, there has been in all cases a failure of the most decided kind. The so-called preventive system has failed. A work may be permitted to begin because within the law, but it extends and infringes laws. Must it be taken to a new place on such extension? To do so would frequently cause bankruptcy. This is one important reason why the preventive system has failed. ${ }^{151}$

It would appear from the above that Smith has changed his mind regarding the benefits of licensing which he seemed to endorse in his report the previous year. Yet we find him making the following licence-like proposal in his Ninth Annual Report:

I cannot avoid thinking that some relief will be found in the suggestion made some time ago to have the air examined when new manufactories are proposed, and if the atmosphere is injured to a certain extent, to allow no more of the same manufactories at the place. This will give a maximum limit of bad air. Improved methods will allow a place to increase, but not inferior methods. ${ }^{152}$

He repeated the argument in a speech he delivered in 1876, where he said:

I am inclined to say that it might fairly be laid down that no chemical works, giving out any of the acids mentioned, should be built, unless a certain much higher degree of purity than is attained now were obtained; and for muriatic acid I may say that I am so fully satisfied with late results in certain quarters, that I should put the maximum at a very low figure... When new works were put under this pressure, old ones would follow in time. ${ }^{153}$

150 Ibid, 1867 Fourth Annual Report (London 1868) 89.

151 Ibid 115 .

152 Inspector of Alkali Works, 1872 Ninth Annual Report (London 1873) 35.

153 R Angus Smith, 'What Amendments Are Required in the Legislation Necessary to Prevent the Evils Arising from Noxious Vapours and Smoke?' [1877] Transactions of the National Association for the Promotion of Social Science 495, 532. 
Yet in testimony he gave that very year before the Royal Commission on Noxious Vapours (discussed below), he rejected the idea of creating industrial districts of the type found in Belgium and Germany and described the concept as 'rather different to our usual ideas of things in England'. ${ }^{154}$

The discrepancy between the latter two statements might be explained through the distinction between districting (designed to concentrate polluting industries in designated locales), and licensing (geared at the implementation of improved control technology). The same cannot be said of Smith's seeming fluctuations vis-à-vis the benefits of the Continental 'preventive system' as such. What is quite clear, however, is the salience of the continental alternative to the regulatory discourse of Smith's time in the Inspectorate. In interpreting Smith's inconsistencies and ambiguity regarding the preventive approach, it is likewise important to keep in mind the political constraints inherent in the Alkali Inspectorate's subordination to the Board of Trade, and, from 1872, the Local Government Board. John Lambert, who headed the Local Government Board, was sceptical of centralised enforcement and favoured strengthening the authority of local government institutions, in keeping with the sentiments of the anti-centralisation movement. John Simon shared this perspective, and both men testified to this effect before the Royal Commission on Noxious Vapours. ${ }^{155}$ Implementing a licensing regime under the auspices of the Alkali Inspectorate would have entailed increased centralisation and, as such, Smith had good reason to suspect that the prospect cut against the wishes of his superiors in the Local Government Board. It is perhaps relevant in this connection that Smith encountered difficulties when he sought to procure funding from the Local Government Board for travel to Holland and France for the purpose of observing chemical works there. Though Smith eventually received some funding for his travel, the request was initially declined and partially granted only after Smith submitted a letter detailing the benefits he expected from this type of comparative investigation. ${ }^{156}$

The Royal Commission on Noxious Vapours was convened in 1876 in response to growing public concern with industrial pollution and mounting political pressures for more stringent regulatory controls. The Committee heard from 197 witnesses over a period of almost two years and published its report in 1878. The option of adopting the continental licensing approach was among the alternatives put before the Committee for consideration. Notably, it was a chemical manure manufacturer who was among the most enthusiastic supporters of the licensing approach. His testimony built in this respect on his experience establishing a facility in Germany (together with a German

154 The Royal Commission on Noxious Vapours, 'Report of the Royal Commission on Noxious Vapours Presented to both Houses of Parliament by Command of Her Majesty' (C ( $2^{\text {nd }}$ series) 2159) 1878 [313].

155 Ibid.

156 MacLeod (n 10) 104. 
partner) and the contrast between that experience and the situation he faced in England where 20 years after establishing his works he was now facing pressures to move as the surrounding community became increasingly intolerant of the smell. This type of eventuality, he implied, was precluded in Germany where the building of works was conditioned on the government's approval. For this reason he believed that if some kind of plan like that could be pursued with regard to the erection of works in England it would be more satisfactory than that we should be allowed to put works up and be allowed to exist for 20 years, and then be told that we must not use them any longer, or do something which I say is impossible. ${ }^{157}$

The Royal Commission made reference in its report to a suggestion put before it that 'a veto might be given to a government department, such as the Local Government Board, on the erection of new chemical works in districts where such works do not at present exist, or more generally on the erection of any new chemical works whatever. ${ }^{158}$ But, gesturing towards the anticentralists, it rejected the proposal under the argument that the exercise of such a veto scarcely seems to us a legitimate function of government. ${ }^{159}$ As the Report made evident, the very legitimacy of legislative interference in business and attendant inspection remained contested at the time. In this connection it quoted the testimony of Hussey Vivian, a member of Parliament and the owner of a large copper smelter in Swansea, that as an Englishman, he objected to 'inspection of any kind ... to the greatest degree. ${ }^{160}$ Vivian's objection, as the Report explained, was based in a deeply rooted, but still resonant, common law principles: 'Mr. Vivian argues, and he is far from being alone in his views, that the law of the land should provide adequate remedies for all injuries and nuisances, and that aggrieved individuals should be left to vindicate their rights and seek compensation for their wrongs in the courts of law. ${ }^{161}$ However, in the final analysis, as the Report pointed out, the great majority of the witnesses, including the Alkali manufacturers, supported the continuation of centralised inspection.

\subsection{Best Practicable Means}

Next to licensing, the most ambitious reform proposal put before the Royal Commission came from FA Fletcher, the man who would in time replace Smith as Chief Inspector. Fletcher called for a general Act requiring the

157 The Royal Commission on Noxious Vapours (n 154) [9242].

158 Ibid 33.

159 Ibid.

160 Ibid 27.

161 Ibid. 
employment of the 'best practicable means' (BPM) for the prevention or mitigation of all noxious vapours. ${ }^{162}$ The proposal built on the language of an 1874 Amendment to the original Alkali Act. Under that Act, the Alkali Inspectorate's jurisdiction extended beyond hydrochloric acid to all noxious gases emitted by Alkali works. But whereas hydrochloric acid was subject to a numeric standard (to which the 1874 Act added a new one), it was felt that available information precluded the setting of similarly exact standards where other alkali gases were concerned. As a consequence, in lieu of specifying an emission standard, the 1874 Act required owners of alkali works to 'use the best practicable means of preventing the discharge into the atmosphere' of noxious gases, other than hydrochloric acid. ${ }^{163}$

Under the Nuisances Removal Act, as well as other similar legislation, BPM functioned as a defence against nuisance prosecutions through the granting of a de facto exemption from nuisance liability to those who deployed such means. ${ }^{164}$ This approach allowed for indirect enforcement of technology-based standards. This was the model followed under the Rivers (Pollution Prevention) Act of 1876 which coupled a prohibition on pollution by solid matter with a defence allowing escape from liability where the "best practicable and available means' to make the deposit harmless have been taken. ${ }^{165}$ The 1874 Alkali Act Amendment deviated from this model in that it defined the enforcement authority of the Inspectorate in reference to the 'best practicable means standard, which functioned in this fashion as a positive regulatory mandate. Smith viewed this strategy as a temporary measure made necessary by the difficulty of setting more precise standards. ${ }^{166}$ He viewed exact numerical standards, of the type applicable to hydrochloric acid, as superior to the

162 Ibid 33.

163 The Alkali Act 1874 (37 \& 38 Vict c 43).

164 Nuisances Removal and Diseases Prevention Act 1855 s XXVIL (18 \& 19 Vict c 121).

165 Continental regulatory practices regarding water pollution were explicitly consulted in the process leading to the Rivers (Pollution Prevention) Act. On October 21, 1868 the Secretary to the Commission appointed to study the problem of river pollution, S J Smith, issued the following request:

$[\mathrm{H}]$ aving been informed that the Prussian Government exercises strict supervision over manufactories, in order to prevent as far as possible the pollution of rivers, I am directed to request that application may be made to them for a copy of the enactments in force in Prussia for that purpose... It is most desirable that the Commissioners should be in possession of the enactments and regulations in force in other countries in order that they may be enabled to meet objections which may be made to interference on the part of the government of this country, with the different branches of trade and manufacture that now so seriously pollute the rivers.

(Royal Commission on River Pollution, 'Report of the Royal Commission on River Pollution' (1870) vol II 283.) The Commission's Report reproduced the laws pertaining to river pollution in Prussia, France and other continental countries.

166 Ashby and Anderson (n 12) 40. 
vague mandates inherent to the BPM formula. Fletcher, in contrast, valued the inherent flexibility of the BPM approach, over statutory enumeration of emission standards. Responding to the argument of some of those who expressed fear before the Noxious Vapours Commission that the BPM standard 'is not sufficiently definite and binding on the manufacturer' Fletcher expressed the view that BPM would in fact 'be more binding than a definite figure, even if that could be given, for it is an elastic band, and may be kept always tight as knowledge of the methods of suppressing the evils complained of increases. ${ }^{167}$

The primary benefit that BPM offered over statutory emission standards was that it bypassed the need for Parliament to step in with a statutory amendment whenever improvements in pollution control technology justified tightening the standards. The emission standard that the Alkali Act of 1863 set remained unaltered until the passage of the Alkali Act Amendments of 1874, 11 years later. By that time the original standard was seriously out of date, but the Alkali Inspectorate lacked the jurisdiction to tighten the standard on its own. ${ }^{168}$ Speaking to this issue, Smith suggested in a speech he delivered in 1876 that the solution might lie in allowing the Local Government Board to issue an order, subject to retroactive sanctioning by Parliament, changing the applicable limits as necessary.

Smith was referring in this connection to what was then a novel practice under which, in order to increase the speed and efficiency of administrative action, Parliament authorised executive agencies to issue orders modifying existing legislation when found necessary (with the requirement that these changes be subsequently given parliamentary approval). By the start of the 20th century, this practice would be at the center of a bitter political controversy, with opponents terming the pertinent legislation 'Henry VIII clauses' after the 1539 'Statute of Proclamations' which Parliament passed during Henry VIII's reign. ${ }^{169}$ The 1539 Act aimed to legitimate the controversial practice of royal proclamations by conferring upon it explicit parliamentary authorisation. ${ }^{170}$ Those who invoked the phrase 'Henry VIII clauses' at the start of the 20th century sought to analogise executive lawmaking of their days to Tudor and Stewart absolutism. ${ }^{171}$ The constitutional question on the table was the same one Fortescue put forth when he argued for the absence of prerogative lawmaking authority under common law. ${ }^{172}$

167 The Royal Commission on Noxious Vapours (n 154) [6590].

168 Smith (n 153) 532.

169 - 'Departmental Legislation' Times of London (London 16 February 1929) 13.

170 Statute of Proclamations 1539 (31 Hen 8 c 8).

171 Rt Hon Lord Hewart, The New Despotism (Ernest Benn, London 1929).

172 N Morag-Levine, 'Agency Statutory Interpretation and the Rule of Common Law' (2009) 2009 Mich St L Rev 51. 
The controversy was still in its infancy during Smith's time, but already sufficiently present to lead Smith to choose his words with caution:

It shows that the same powers ought to be proceeded with, but with somewhat more speed. There were eleven years between the first and second Alkali Acts, a most unnecessary time. This suggested to me the propriety of having the strictness of the tests increased by a more rapid method than an Act of Parliament. This might be done by an order of the Government, for example, of the Local Government Board, with the sanction of Parliament, a method not without precedent, as I understand, and less liable to cause delays, than when the usual course of a Bill is to be run. ${ }^{173}$

The great benefit inherent to the BPM formula was its ability to allow for flexibility and timely change in applicable standards. A law such as the one Fletcher advocated would have conferred on the Inspectorate almost complete discretion to regulate all sources of noxious gases and to adjust this regulation as circumstances changed, with little if any need to return to Parliament. The majority of manufacturers supported the concept, ${ }^{174}$ a fact suggestive of their trust that the Inspectorate would not turn BPM into an overly harsh regulatory instrument. But the Noxious Vapours Commission was reluctant to recommend such a revolutionary step, and instead opted for a number of incremental measures, including ones that would set the stage for the future ascendance of BPM in British regulation.

The recommendations of the Royal Commission were by and large reflected in the Alkali Etc. Amendment Act (1881). ${ }^{175}$ The Act, for the first time, extended the Alkali Act's jurisdiction beyond Alkali works to a closed list of scheduled industrial processes including the manufacturers of sulphuric acid, chemical manure, nitric acid, sulphate and muriate of ammonia, chlorine salt and cement. The standard applied to these processes was BPM, since the state of knowledge regarding pertinent pollution control capabilities was deemed insufficient to support numeric standards. ${ }^{176}$ The Act deviated from Fletcher's original proposal in that it listed the works to be subject to BPM, rather than conferring on the Inspectorate blanket authority to subject all polluting industries to BPM. This left in place the need for Parliament to revise the list of scheduled industries through legislation. Fletcher alluded to this problem in an article he published in 1888: '[s]carcely is the ink dry with which such a list is written than works are established or processes are added to those

173 Smith (n 153) 532.

174 Ashby and Anderson (n 12) 41.

175 Alkali \&c Amendment Act 1881 (44 \& 45 Vict c 37).

176 Macleod (n 10) 108. 
already existing, which had they been known sooner, would certainly have been included. ${ }^{177}$ Nonetheless, the same article declared ' $[\mathrm{t}]$ he Act of 1881 is thus a great advance on those of 1863 and 1874, especially in that the principle is introduced of throwing on the manufacturer an obligation to employ the best known methods for preventing the escape of noxious gas, or otherwise avoiding a nuisance. ${ }^{\text {, }}{ }^{17}$

Written by one of the Inspectors for the Alkali Inspectorate, the article went on to offer a first-hand account of the benefits associated with BPM:

[T] he phrase not only goes beyond and is independent of definite fixed standards- it also constructs them. If it can be shown, after prolonged observation, that in conducting some process of manufacture a certain amount of success in controlling noxious emanations is usually achieved, this result becomes a basis for the future, a standard to which all are expected to conform: and this standard has the great advantage over one rigidly fixed by Act of Parliament, that it is one which accommodates itself to the varying conditions of manufacture and the changing light which knowledge brings to bear on it. In that the Act of 1881 embodies this principle, and enjoins in conducting certain manufacturing processes that the best practicable means shall be used for preventing the discharge into the atmosphere of all noxious gases evolved in such work, it makes a great advance over the past legislation on this subject. ${ }^{179}$

Fletcher, who became Chief Inspector after Smith's death in 1884, continued in the capacity to press for the passage of a general noxious vapours Act, that would eliminate the need to add new processes by legislation, but was unsuccessful in his effort. ${ }^{180}$ Thirteen scheduled works were added to the list of regulated industries when the Alkali Act was again revised in 1892. And in 1906 (by then under a new Chief Inspector) the Act was further expanded and consolidated into the mold that would remain in force (subject to periodic updating of the list of scheduled sources) up until the 1980s. ${ }^{181}$

The 1906 Act included, for the first time, a statutory description of 'best practicable means' which included, beyond the design of furnaces and other equipment, proper maintenance of applicable technology and supervision of all processes responsible for emitting noxious gasses within a facility. ${ }^{182}$ In actuality, however, the meaning of the BPM concept was to be found in the unwritten laws at the core of a regulatory tradition dating to the earliest days of

177 A Fletcher, 'The Present State of the Law Concerning the Pollution of Air and Water' (1888) 36 J Soc Arts 567, 574.

178 Ibid 573.

179 Ibid 574.

180 Ashby and Anderson (n 12) 69-70.

181 Alkali, \&c Works Regulation Acts 1906 (6 Edw 7 c14). By 19792884 processes were under the jurisdiction of the Alkali Act. Hill (n 8) 166.

182 Alkali, \&c Works Regulation Act 1906 s 27(6 Edw 7 c14). 
the Inspectorate. Speaking to Parliament not long after the Alkali Act first came into effect, Lord Derby expressed his profound satisfaction at the way things were proceeding under the Inspectorate: 'I am sure I only express a universal opinion when I say that the Board of Trade could not have made a better appointment than that of Dr Angus Smith, whose scientific knowledge is universally known, and who has conducted the proceedings under the Act in so conciliatory a spirit as to have tended materially to the success of the Act. ${ }^{\text {, }}{ }^{13}$ With the recent precedent of Edwin Chadwick in mind, Angus Smith committed to a collaborative model of governance. The enthusiastic endorsement of a Conservative leader of Lord Derby's stature attests to his success in this regard. $^{184}$

The impact of the anti-centralisation movement, and its underlying common law sensibilities, is likewise reflected in the manner in which the BPM standard accommodated variation in local economic and geographical circumstances. Smith addressed this issue in his annual report on the Inspectorate's activities in 1871 in the context of the difficulties inherent in the absence of a clear-cut definition for a nuisance and the attendant conflict surrounding it. It would be, he argued, "very desirable to enable us to say distinctly: this is allowed and no more. ${ }^{185}$ At the same time, he made a point of emphasising that any such standard must allow for variation in reference to the conditions of diverse locales: '[i]t would be very unfair to make a general law fixing the meaning of a nuisance to be the same in all conditions. Why should a manufacturer established in a desert part of the county be treated like one in a crowded thoroughfare? Or when no one complains, or, rather, when no one is hurt, why should the mere formality of keeping a law be observed? 186

Of the various factors Smith outlined as potentially relevant to the appropriate severity of regulatory standards, it is his reference to the absence of complaints as reason for more lax standards that is particularly instructive. As Jules Vilain wrote in 1857, the distinction between reactive and preventive regulation marked the dividing line between the English and continental

183 Hansard HL vol 179 cols 631-36 (22 May 1865).

184 Amplifying his earlier statement, Lord Derby went on to note:

I would be the last man to ask the Government to undertake, or to venture myself upon a Quixotic attack upon the various processes of those manufactures which form the staple of the wealth of this country, and with which my own interests are closely connected; but I hope the successful results of this experiment will have the effect of allaying any jealously or apprehensions which may be felt by manufacturers in kindred branches of trade, and to encourage the Government to proceed cautiously, but steadily, with the object of introducing measures for the purpose of removing many nuisances which at present unnecessarily accompany many of our manufacturing processes.

(Ibid 635).

185 Inspector of Alkali Works, 1871 Eighth Annual Report (London 1872) 5.

186 Ibid. 
approaches. It was because, in England, pollution control was contingent on local political and legal mobilisation that, at least by some accounts, English industrialists could bypass pollution controls by locating among poorer populations that lacked the resources to bring about effective intervention. In tying its enforcement decisions to local complaints, the Alkali Inspectorate retained elements of this reactive tradition.

The Alkali Act gave rise in this fashion to a hybrid regulatory approach which melded preventive implementation of technology standards with case-by-case decision making in the style of the common law. The emergence of this distinctly British approach simultaneously speaks both to the weakness and the strength of common law principles in 19th century British regulatory politics. The evident incapacity of reactive common law institutions to adequately respond to problems of industrial pollution exerted powerful pressures for Britain to adopt a preventive regime similar to the continental approach. At the same time, the ability of opponents to appeal to deep-seated antagonism towards continental law across centuries of British constitutional history, made it politically difficult, if not impossible, for reformers to directly transplant continental regulatory institutions into Britain, as Chadwick's experience perhaps best illustrates. The result was a synthetic adaptation of preventive, technology-based, continental regulation to common law sensibilities under a uniquely British BPM approach.

\section{Conclusion}

Writing in 1981 against emergent tensions between Britain and continental Europe over environmental policy, Ashby and Anderson wrote in the conclusion of a book largely devoted to the history of the Alkali Act:

The Alkali Act is administered in a way that tries to reconcile the often conflicting interest of the public who want clean air, the manufacturer who wants to make a profit, the employees who want to keep their jobs and to get a good wage, and the government who wants national prosperity. Such a remit as this is incompatible with the imposition of inflexible fixed emission standards; it requires a separate value judgment for each set of circumstances. ${ }^{187}$

Elsewhere in the same book they more explicitly tackled the comparison with the Continent: '[p]rogress by 'Minute Particulars': this has been a characteristic of the evolution of policy for the control of pollution in Britain ... in our view 
it is one reason why this policy-compared with the policies of some other countries-has proved workable.188

Differences between the British and continental approaches have lost much of their salience since the 1980s through a series of mutual adjustments between EU and British regulatory instruments. ${ }^{189}$ In the process, long-standing paradigms of the British approach to regulation have been fundamentally transformed. ${ }^{190}$ In turn, Britain was able to shape elements of the EU's environmental regime in accordance with its traditional approach. Especially important in this connection, as Andrew Jordan has noted, is the IPPC Directive's attention to local conditions in the setting of BAT standards. ${ }^{191}$

Irrespective of the ultimate impact of the EU on the resilience of the British approach to regulation, an appreciation of the common law's historical role in the forging of that approach is of significant contemporary relevance. First and foremost, this is because of the ability of the British story to shed light on the common law's continuing impact on American environmental policy and contemporary divisions over the precautionary principle. Both in the context of American-British and British-continental comparisons, the centrality of the BPM concept within the British approach has obscured the common law's explanatory power. In the first instance, the 19th-century emergence in Britain - but not in the United States-of a centralised, technology-linked, regulatory regime highlighted differences, rather than similarities between these two common law countries. At the same time, underlying similarities between BPM and continental technology standards likewise argued against the characterisation of technology standards as a civil law instrument. Implicit to both sets of arguments, however, is the understanding of the Alkali Act itself as an indigenously British development, rather than a law modelled on continental examples. In contrast, if the Alkali Act was itself the product of continental influences, it becomes easier to reconcile the long-standing presence of precautionary technology standards in Britain with the civil law characterisation of such standards. This in turn, should prompt greater attention to the influence of legal traditions in studies of national legal styles and comparative environmental politics more generally.

188 Ibid 70.

189 Ball and Bell (n 5) 107.

190 A Jordan, The Europeanization of British Environmental Policy: A Department Perspective (Palgrave Macmillan, New York 2002) 189.

191 Council Directive (EC) 2008/1/EC of the European Parliament and of the Council of 15 January 2008 concerning integrated pollution prevention and control [2008] OJ L24/8. Jordan describes the IPPC Directive as 'a curious hybrid of British and German approaches' and cites the fact that the IPPC 'explicitly mentions that local conditions must be taken into account in determining BAT' in support of the argument that '[i]n many important respects, the IPPC Directive does not disrupt Britain's basic paradigm underpinning industrial air pollution control' (ibid 165). 